\title{
A Tri-Stimuli Responsive (Maghemite/PLGA)/Chitosan Nanostructure with Promising Applications in Lung Cancer
}

\author{
Fátima Fernández-Álvarez ${ }^{1}$, Gracia García-García ${ }^{2} \mathbb{D}$ and José L. Arias ${ }^{1,3,4, *(D)}$ \\ 1 Department of Pharmacy and Pharmaceutical Technology, Faculty of Pharmacy, University of Granada, \\ 18071 Granada, Spain; fatimaferal@ugr.es \\ 2 Faculty of Experimental Sciences, Universidad Francisco de Vitoria, 28223 Madrid, Spain; gracia.garcia@ufv.es \\ 3 Institute of Biopathology and Regenerative Medicine (IBIMER), Center of Biomedical Research (CIBM), \\ University of Granada, 18071 Granada, Spain \\ 4 Biosanitary Research Institute of Granada (ibs.GRANADA), Andalusian Health Service (SAS), \\ University of Granada, 18071 Granada, Spain \\ * Correspondence: jlarias@ugr.es; Tel.: +34-958-24-39-00
}

check for updates

Citation: Fernández-Álvarez, F.; García-García, G.; Arias, J.L. A Tri-Stimuli Responsive (Maghemite/PLGA)/Chitosan Nanostructure with Promising Applications in Lung Cancer. Pharmaceutics 2021, 13, 1232. https: / / doi.org/10.3390/ pharmaceutics 13081232

Academic Editors:

Rafael Vazquez-Duhalt,

Karla Juarez-Moreno and

Josué D. Mota-Morales

Received: 6 July 2021

Accepted: 6 August 2021

Published: 10 August 2021

Publisher's Note: MDPI stays neutral with regard to jurisdictional claims in published maps and institutional affiliations.

Copyright: (c) 2021 by the authors. Licensee MDPI, Basel, Switzerland. This article is an open access article distributed under the terms and conditions of the Creative Commons Attribution (CC BY) license (https:// creativecommons.org/licenses/by/ $4.0 /)$.

\begin{abstract}
A (core/shell)/shell nanostructure (production performance $\approx 50 \%$, mean diameter $\approx 330 \mathrm{~nm}$ ) was built using maghemite, PLGA, and chitosan. An extensive characterization proved the complete inclusion of the maghemite nuclei into the PLGA matrix (by nanoprecipitation solvent evaporation) and the disposition of the chitosan shell onto the nanocomposite (by coacervation). Short-term stability and the adequate magnetism of the nanocomposites were demonstrated by size and electrokinetic determinations, and by defining the first magnetization curve and the responsiveness of the colloid to a permanent magnet, respectively. Safety of the nanoparticles was postulated when considering the results from blood compatibility studies, and toxicity assays against human colonic CCD-18 fibroblasts and colon carcinoma T-84 cells. Cisplatin incorporation to the PLGA matrix generated appropriate loading values $(\approx 15 \%)$, and a dual $\mathrm{pH}$ - and heat (hyperthermia)-responsive drug release behaviour $\left(\approx 4.7\right.$-fold faster release at $\mathrm{pH} 5.0$ and $45{ }^{\circ} \mathrm{C}$ compared to $\mathrm{pH} 7.4$ and 37 $\left.{ }^{\circ} \mathrm{C}\right)$. The half maximal inhibitory concentration of the cisplatin-loaded nanoparticles against human lung adenocarcinoma A-549 cells was $\approx 1.6$-fold less than that of the free chemotherapeutic. Such a biocompatible and tri-stimuli responsive (maghemite/PLGA)/chitosan nanostructure may found a promising use for the effective treatment of lung cancer.
\end{abstract}

Keywords: chitosan; heat-triggered drug release; magnetic drug delivery; $\mathrm{pH}$-responsive drug release; PLGA; triple stimuli-responsive nanoparticle

\section{Introduction}

Control of the in-vivo fate of antitumour agents (genes and/or drugs), when they are site-specific delivered by biodegradable and biocompatible nanoparticles (NPs), has been reported to optimize cancer therapy outcomes in terms of efficacy and safety [1-3]. Remarkably, Nanotechnology has also contributed to the implementation of combination therapies against this malignant disease, e.g., chemotherapy and photodynamic therapy [4], chemotherapy and photothermal therapy [5], and chemotherapy and hyperthermia [6].

To these objectives, the introduction of passive and active drug targeting strategies in NP engineering has resulted to be a key aspect to be seriously considered $[7,8]$. These wise formulation strategics are focused on the surface functionalization of the NP structure with: (i) hydrophilic polymer chains, classically poly(ethylene glycol) (PEG), to develop stealth particles that can exploit the enhanced permeability and retention (EPR) effect commonly found at the tumour site [9]; and, (ii) molecules capable of interacting with receptors at the cancer cell membrane (ligand-mediated targeting) [10]. Also, the nanostructure can be optimized to assure the triggered (selective) release of the chemotherapeutics in deep contact with the malignant cells. The later are stimuli-sensitive drug delivery systems 
releasing loaded contents on demand when they suffer modifications in their properties and architecture under specific bioenvironmental changes [11]. In this line, the development of nanoparticulate systems exhibiting a pH-responsive drug release behaviour [12,13], or heat (hyperthermia)-triggered drug release capacities [14,15], has been described to facilitate a better accumulation of the chemotherapeutics at the tumour mass. Probably, a more relevant approach to beat the challenges is the formulation of multi-stimuli responsive nanostructures if optimized levels of the antitumour agent are intended in deep contact with the cancer cells or even intracellularly. To that aim, nanoengineering strategies became more complex and difficult to develop [16,17].

In this scenery, superparamagnetic iron oxides are considered to be relevant nanomaterials when engineering the structure of a multi-stimuli sensitive nanomedicine against cancer [18-21]. Maghemite $\left(\gamma-\mathrm{Fe}_{2} \mathrm{O}_{3}\right)$ and magnetite $\left(\mathrm{Fe}_{3} \mathrm{O}_{4}\right)$ are the iron oxide particles preferably introduced in the structure of magnetic nanomedicines [22]. More concretely, including $\gamma-\mathrm{Fe}_{2} \mathrm{O}_{3}$ nuclei in the architecture of nanoparticulate system has been described to report interesting drug delivery properties (efficient tumour targeting in response to a magnetic field located at the cancer site) [23-25], magnetic hyperthermia characteristics to trigger drug release and/or to generate a complementary antitumour mechanism [26,27], and magnetic resonance imaging (MRI) contrast properties to visualize the malignant tissue and cells $[28,29]$.

However, the architecture of the iron oxide-based nanosystems must be improved to assure the safety, biocompatibility, and stability of the magnetic colloid, and the vehiculization and targeting of the therapeutic agents (drugs and/or genes). For instance, which is possible when using polymers in the surface functionalization of these NPs: poly(D,Llactide-co-glycolide) (PLGA) [30], chitosan (CS) [31], or poly(e-caprolactone) [32], to cite just three representative examples.

PLGA nanomatrices can be advantageously used in the formulation of magnetic nanocomposites to obtain appropriate loadings and controlled (biphasic) release profiles of chemotherapeutics [33-35]. In addition, $\mathrm{pH}$-triggered drug delivery capabilities have been described for this biocompatible copolymer. A consequence of its improved degradation at the acidic intratumoural $\mathrm{pH}$ by hydrolysis of the backbone ester linkages in its chemical structure [36,37]. PLGA has been also used to prepare thermoresponsive nanocarriers generating a heat-triggered release of the cargo at the targeted site [38,39]. In fact, it has been defined an increase in the rate of polymer degradation with increasing incubation temperatures [40], and the enhancement of the mobility of the PLGA chains at temperatures over the glass transition temperature $\left(T_{\mathrm{g}}\right)$ of PLGA $\left(\approx 40^{\circ} \mathrm{C}\right)[39]$, being these key factors activating a rapid release of the cargo. Thus, drug release from PLGA matrices could be triggered when superparamagnetic iron oxide nuclei are embedded into them: a high frequency alternating electromagnetic field will transform these magnetic cores into heaters producing an increase in temperature to $\approx 45^{\circ} \mathrm{C}[18,22,41]$, over the $T_{\mathrm{g}}$ of the polymer. As a result, a fast drug release would take place at this temperature given the greater polymer degradation and also because of the improved drug diffusion of the chemotherapeutic molecules through the PLGA structure.

Like PLGA nanostructures, CS-based nanosystems are efficient in the tumour $\mathrm{pH}-$ responsive release of drugs, given the high solubility of the polymer at these acidic $\mathrm{pH}$ values $[42,43]$. Additionally, CS is a biocompatible and water-soluble polymer that could be considered as an alternative to poly(ethylene glycol) (PEG) chains when engineering long-circulating NPs. Hence, surface functionalization with CS may optimize the biodistribution and therapeutic effects of PLGA-based nanomedicines by: (i) providing hydrophilic and positively charged stealth coatings that could reduce or even inhibit protein corona formation, thus minimizing and delaying the opsonization process to evade phagocytosis [44-47], while favouring the uptake by targeted cells [48,49]; and, (ii) creating an additional barrier to drug diffusion during the early-time burst release of the biphasic drug release profile [50,51]. Incorporation of the CS shell onto a PLGA-based NP may take place by an attractive interaction between the negative PLGA matrix and the positive 
polysaccharide [52], and the idea has been applied to the production of magnetopolymer particles, i.e., $\left(\mathrm{Fe}_{3} \mathrm{O}_{4} / \mathrm{PLGA}\right) / \mathrm{CS}[53,54]$ and $\left(\gamma-\mathrm{Fe}_{2} \mathrm{O}_{3} / \mathrm{PLGA}\right) / \mathrm{CS}$ [55] nanostructures. However, the multi-stimuli-responsive character of these (core/shell)/shell composites has not yet been characterized.

Cisplatin, Cisplatinum, or cis-diamminedichloroplatinum(II) (CDDP) dichloride [molecular weight, $\mathrm{M}_{\mathrm{W}}: 300.05 \mathrm{~g} / \mathrm{mol}$; water solubility: $2.53 \mathrm{mg} / \mathrm{mL} ; n$-octanol-water partition coefficient $\left.\left(\log P_{\mathrm{OW}}\right):-2.19\right]$ has demonstrated an appropriate activity against solid tumours, e.g., lung cancer, ovarian cancer, head and neck squamous cell carcinoma breast cancer, and brain cancer [56], when administered as a single antitumour agent or in a combination chemotherapy regimen. Unfortunately, rapid biodegradation of CDDP molecules in blood could be considered a key limitation to conventional chemotherapy (human plasma half-life $\leq 0.5 \mathrm{~h}$ ) [56,57]. To beat the challenge, it has been proposed the incorporation of this chemotherapeutic into nanocarriers, e.g., PLGA- $[58,59]$ or CS-based NPs $[31,60]$. That association has reported optimized pharmacokinetics along with improved contact of the anticancer molecules with the malignant cells. Nevertheless, greater benefits have been associated to the engineering of stimuli-responsive nanostructures for $\mathrm{pH}$-triggered $[37,61]$ and/or heat (hyperthermia)-triggered [41,62] drug release: CDDP release in blood is kept to a minimum while a rapid release is then activated when the $\mathrm{pH}$-responsive colloid reaches the tumour interstitium $(\mathrm{pH} \approx 5)$, and/or when this targeted site is coupled to a high frequency alternating electromagnetic field transforming the superparamagnetic iron oxide cores included in the nanostructure into heaters that produce heat in a controlled manner (maximum temperature of $\approx 45^{\circ} \mathrm{C}$, not causing damage to healthy tissues surrounding the tumour mass). CDDP has also been previously loaded to non-magnetic PLGA/CS-based particles [49,63], but up to now the colloidal stability, hemocompatibility, and suitability of these (core/shell) nanoparticulate systems for (dual) $\mathrm{pH}$-triggered and heat (hyperthermia)-triggered CDDP release was not characterized.

In this contribution, we have investigated a procedure to formulate NPs in which $\gamma-\mathrm{Fe}_{2} \mathrm{O}_{3}$ nanocores are included into a PLGA matrix loaded with CDDP molecules and surface functionalized by CS. Reproducible production of this $\left(\gamma-\mathrm{Fe}_{2} \mathrm{O}_{3} /\right.$ PLGA)/CS nanostructure was demonstrated by comparing some relevant physical and chemical properties to those of $\gamma-\mathrm{Fe}_{2} \mathrm{O}_{3} /$ PLGA and CS particles. Evaluation of the toxicity of the nanocomposites was based on hemocompatibility studies, and tests on human colonic CCD-18 fibroblasts and human colon carcinoma T-84 cells. After defining the short-term stability of the colloid and the in-vitro interaction with BSA, the characterization of the multi-stimuliresponsive capabilities of these (core/shell)/shell composites started with the analysis of their magnetic responsiveness. Then, CDDP loading to the NPs and in-vitro release was evaluated by ultraviolet (UV) spectrophotometry. The potential use of the nanoplatform for (dual) $\mathrm{pH}$-triggered and heat (hyperthermia)-triggered CDDP release was investigated at the acidic microenvironment typical of tumours $(\mathrm{pH} \approx 5)$ and at the temperature used in magnetic hyperthermia to trigger drug release $\left(\approx 45^{\circ} \mathrm{C}\right)$. To finish, cytotoxicity against human lung adenocarcinoma A-549 cells of these CDDP-loaded magnetic nanocomposites was evaluated. To our best knowledge, this is the first time that these $\left(\gamma-\mathrm{Fe}_{2} \mathrm{O}_{3} /\right.$ PLGA $) / C S$ (core/shell)/shell NPs have demonstrated adequate properties as magnetic-, $\mathrm{pH}$ - and temperature-responsive nanostructures for the delivery of CDDP molecules to malignant cells, and promising activity against lung cancer.

\section{Materials and Methods}

\subsection{Materials}

Deionized and filtered water was used in the experiments (Milli-Q Academic ${ }^{\circledR}$, Millipore, Molsheim, France). Resomer ${ }^{\circledR}$ RG 502 H [PLGA, 50:50 poly(D,L-lactide):poly(glycolide), $\mathrm{M}_{\mathrm{W}} \approx 7$ to $17 \mathrm{kDa}$, inherent viscosity $\approx 0.16$ to $0.24 \mathrm{dL} / \mathrm{g}$ ), low $\mathrm{M}_{\mathrm{W}} \mathrm{CS}$ ( $\approx 50$ to $190 \mathrm{kDa}$, determined by viscosity measurement; polydispersity not determined by the laboratory; $75-85 \%$ deacetylated; $99 \%$ purity level), ethylenediaminotetraacetic acid (EDTA), monosodium citrate $\left[\mathrm{NaH}_{2}\left(\mathrm{C}_{3} \mathrm{H}_{5} \mathrm{O}(\mathrm{COO})_{3}\right)\right]$, cis-diamminedichloroplatinum(II) (CDDP) 
dichloride, 3-(4,5-dimethylthiazol-2-yl)-3,5-diphenyl tetrazolium bromide (MTT) solution, Dulbecco's modified eagle's medium (DMEM), phosphate buffered saline (PBS), bovine serum albumin (BSA; heat shock fraction, $\geq 98 \%$ purity level), fetal bovine serum (FBS), and Penicillin-Streptomycin solution (containing 10,000 U/mL of Penicillin and $10 \mathrm{mg} / \mathrm{mL}$ of Streptomycin) from Merck KGaA (Gernsheim, Germany). Kolliphor ${ }^{\circledR}$ P-188 from BASF (Ludwigshafen, Germany). Iron(III) nitrate nanohydrate [Fe( $\left.\left(\mathrm{NO}_{3}\right)_{3} \cdot 9 \mathrm{H}_{2} \mathrm{O}, \mathrm{M}_{\mathrm{W}}: 404 \mathrm{~g} / \mathrm{mol}\right]$, iron(II) chloride tetrahydrate $\left(\mathrm{FeCl}_{2} \cdot 4 \mathrm{H}_{2} \mathrm{O}, \mathrm{M}_{\mathrm{W}}: 198.81 \mathrm{~g} / \mathrm{mol}\right)$, potassium nitrate $\left(\mathrm{KNO}_{3}\right)$, perchloric acid $\left(\mathrm{HClO}_{4}, 70 \%\right.$, American Chemical Society, ACS, specification, Washington, DC, USA), hydrochloric acid ( $\mathrm{HCl}, 37 \%$, ACS specification), ethanol (EtOH, $\left.96^{\circ}\right)$, dimethyl sulfoxide (DMSO), and acetic acid $\left(\mathrm{CH}_{3} \mathrm{COOH}, \geq 98 \%\right.$, ACS specification) from VWR lnternational Eurolab S.L.U. (Barcelona, Spain). Iron trichloride hexahydrate $\left(\mathrm{Cl}_{3} \mathrm{FeH}_{12} \mathrm{O}_{6}\right.$, $\mathrm{M}_{\mathrm{W}}: 270.32 \mathrm{~g} / \mathrm{mol}$ ), polyvinyl alcohol (PVA, $\left.\mathrm{M}_{\mathrm{W}}: 72,000 \mathrm{~g} / \mathrm{mol}\right)$, HPLC-grade acetone, citric acid $\left(\mathrm{C}_{6} \mathrm{H}_{8} \mathrm{O}_{7}\right)$, ammonia $\left(\mathrm{NH}_{3}, 30 \%\right.$, ACS specification), and sodium hydroxide $(\mathrm{NaOH})$ from Panreac Química S.L.U. (Barcelona, Spain). Disodium phosphate $\left(\mathrm{Na}_{2} \mathrm{HPO}_{4}\right)$, dipotassium phosphate $\left(\mathrm{K}_{2} \mathrm{HPO}_{4}\right)$, sodium sulfate $\left(\mathrm{Na}_{2} \mathrm{SO}_{4}\right)$, sodium chloride $(\mathrm{NaCl})$, potassium chloride $(\mathrm{KCl})$, and oleic acid ( $\geq 99 \%$, ACS specification) from Guinama S.L.U. (Valencia, Spain). These chemicals were of analytical quality and used as received without further purification.

\subsection{Preparation of the $\left(\gamma-\mathrm{Fe}_{2} \mathrm{O}_{3} / \mathrm{PLGA}\right) / \mathrm{CS}$ Nanostructure}

The procedure followed to obtain $\gamma-\mathrm{Fe}_{2} \mathrm{O}_{3} \mathrm{NPs}$ started with the production of $\mathrm{Fe}_{3} \mathrm{O}_{4}$ particles by chemical co-precipitation (Figure 1a) [64] and finalized with their oxidation into $\gamma-\mathrm{Fe}_{2} \mathrm{O}_{3}$ (Figure 1b) [65] $(n=3)$. To favour the entrapment of the $\gamma-\mathrm{Fe}_{2} \mathrm{O}_{3}$ nanocores into the PLGA matrix, their hydrophilic surface was turned into hydrophobic by using oleic acid [53,66] (Figure 1c) $(n=3)$.

(a)

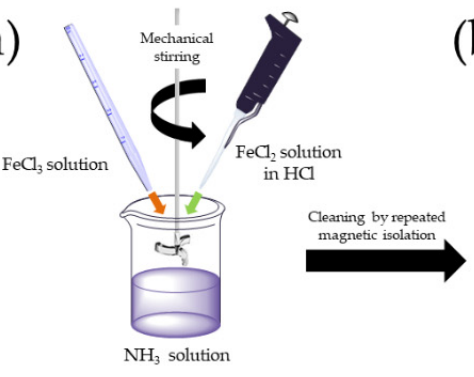

CHEMICAL CO-PRECIPITATION (b)

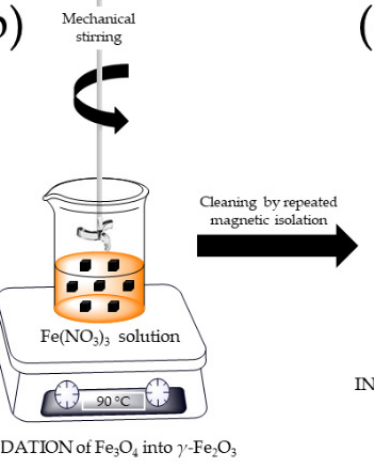

OXIDATION of $\mathrm{Fe}_{3} \mathrm{O}_{4}$ into $\gamma-\mathrm{Fe}_{2} \mathrm{O}$ (c)

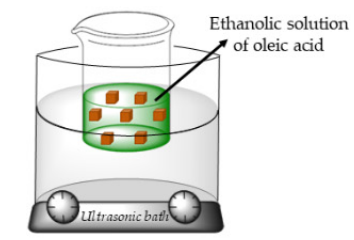

NCORPORATION OF OLEIC ACID onto the $\gamma-\mathrm{Fe}_{2} \mathrm{O}_{3}$ surface (d)

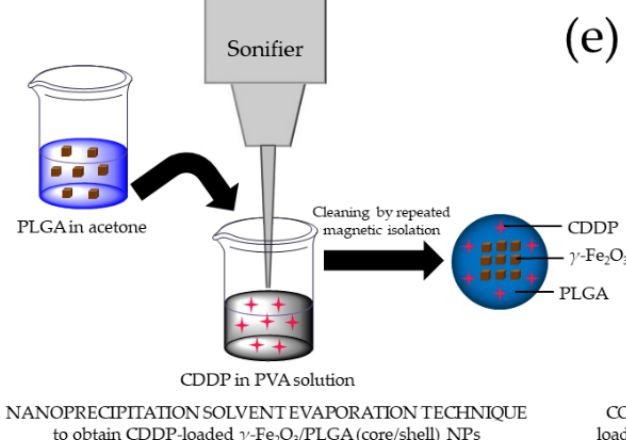

(e)

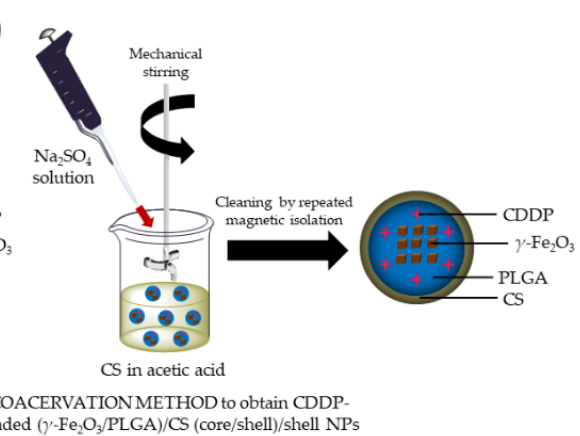

Figure 1. (a) Preparation of $\mathrm{Fe}_{3} \mathrm{O}_{4}$ NPs by chemical co-precipitation and (b) oxidation into $\gamma-\mathrm{Fe}_{2} \mathrm{O}_{3}$ particles; (c) surface modification of $\gamma-\mathrm{Fe}_{2} \mathrm{O}_{3}$ NPs with oleic acid; (d) formulation of CDDP-loaded $\gamma-\mathrm{Fe}_{2} \mathrm{O}_{3} /$ PLGA (core/shell) particles by nanoprecipitation solvent evaporation; and (e) preparation of CDDP-loaded $\left(\gamma-\mathrm{Fe}_{2} \mathrm{O}_{3} / \mathrm{PLGA}\right) / \mathrm{CS}$ (core/shell)/shell NPs by coacervation. 
Preparation of the $\gamma-\mathrm{Fe}_{2} \mathrm{O}_{3}$ /PLGA NPs was based on the nanoprecipitation solvent evaporation procedure (Figure 1d) [55] $(n=3)$, which has been described to generate PLGA NPs [67]. CDDP loading to the core/shell NPs was accomplished by dissolving the antitumour molecule in $10 \mathrm{~mL}$ of the aqueous phase [PVA $(1 \%, w / v)]$, at a given amount (up to $300 \mu \mathrm{g} / \mathrm{mL}$ ), before incorporation of $5 \mathrm{~mL}$ of the acetone phase $(n=3)$.

Finally, $\left(\gamma-\mathrm{Fe}_{2} \mathrm{O}_{3} / \mathrm{PLGA}\right) / \mathrm{CS}$ nanocomposites were formulated by coacervation (Figure 1e) [55] $(n=3)$, a method habitually used to prepare CS NPs [68]. Preparation of CDDP-loaded $\left(\gamma-\mathrm{Fe}_{2} \mathrm{O}_{3} /\right.$ PLGA) /CS particles was done by using the $\gamma-\mathrm{Fe}_{2} \mathrm{O}_{3} /$ PLGA NPs with the higher DL values (i.e., $\approx 16 \%$, see Section 3.3$)(n=3)$. NP production performance $(\mathrm{PP}, \%)$ was calculated by using Equation (1):

$$
\operatorname{PP}(\%)=\frac{\text { amount of NPs obtained }(\mathrm{mg})}{\text { summation of materials used in the preparation of these NPs }(\mathrm{mg})} \times 100
$$

\subsection{Characterization}

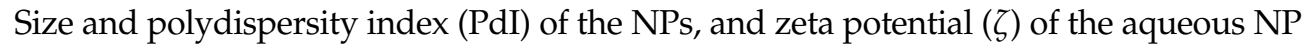
dispersions $(\approx 0.1 \%, w / v)$ were characterized at room temperature and in triplicate (Zetasizer Nano-ZS, Malvern Instruments Ltd., Worcestershire, UK), by photon correlation spectroscopy (PCS) and electrokinetic determinations, respectively. The detection angle was $60^{\circ}$. Furthermore, annular bright field scanning transmission electron microscopy (ABF-STEM), high-angle annular dark field scanning transmission electron microscopy (HAADF-STEM), and high-resolution transmission electron microscopy (HRTEM) (Titan G2 60-300 FEI microscope, Thermo Fisher Scientific Inc., Waltham, MA, USA; accelerating voltage of $300 \mathrm{kV}$ ) facilitated the visualization the particles. Drops of the colloids $(\approx 0.1 \%, w / v)$ were poured on formvar/carbon-coated copper microgrids and dried at room temperature. During the TEM determinations, elemental analysis was done [energy dispersive X-ray (EDX) spectrometer, Bruker Nano GmbH, Berlin, Germany]. Finally, short-term stability of an aqueous dispersion of (core/shell)/shell particles $(1 \mathrm{mg} / \mathrm{mL}, \mathrm{pH} \approx 6)$ at $25.0 \pm 0.5^{\circ} \mathrm{C}$ was tested in triplicate. Evolution of size, PdI and $\zeta$ values of the NPs was measured as a function of time.

Interaction of the nanocomposites with human serum proteins for possible protein corona formation was analysed in vitro, following a previously detailed methodology $[69,70]$. To that aim, $70 \mu \mathrm{L}$ of the magnetic colloid $(9.5 \mathrm{mg} / \mathrm{mL})$ were incubated during $40 \mathrm{~min}$ at $37.0 \pm 0.5^{\circ} \mathrm{C}$ in $5 \mathrm{~mL}$ of PBS (final concentration of $130 \mu \mathrm{g} / \mathrm{mL}$ of PBS) containing 0,34 or $54 \mathrm{mg} / \mathrm{mL}$ of BSA. Size and PdI was then determined by PCS after magnetic removal of the NPs from the media $(0.4 \mathrm{~T}$ permanent magnet) and redispersion in water $(\approx 0.1 \%, w / v)$.

Electrokinetic determinations were done to define qualitatively the surface disposition of CS onto the ( $\gamma-\mathrm{Fe}_{2} \mathrm{O}_{3} /$ PLGA) NPs, given that the technique is most sensitive to small modifications on the surface of iron oxide NPs $[22,71]$. To that objective, the evolution of the $\zeta$ values as a function of the ionic strength (at a constant $\mathrm{pH} \approx 6$ ) was characterized. $\mathrm{KNO}_{3}$ was the electrolyte used to fix the ionic strengths [32,72,73], and the determinations were done at room temperature, after $24 \mathrm{~h}$ of contact under stirring (200 rpm, Boeco universal orbital shaker OS-10, Boeco, Hamburg, Germany) $(n=9)$. With this aim, chemical characterization of the $\left(\gamma-\mathrm{Fe}_{2} \mathrm{O}_{3} / \mathrm{PLGA}\right) / \mathrm{CS}$ particles was also done by Fourier transform infrared (FTIR) spectrometry (FT/IR-6200 spectrometer, JASCO, Easton, MD, USA; resolution of $0.25 \mathrm{~cm}^{-1}$ ). Significant bands of these nanocomposites were identified by comparison with published data.

Given that the internal structure of iron oxide-based particles is considered to be a key factor defining their magnetism [22,74], determination of the mineralogical purity and crystallinity of the $\gamma-\mathrm{Fe}_{2} \mathrm{O}_{3}$ cores and the (core/shell)/shell particles was accomplished by X-ray diffractometry (Philips PW1710 diffractometer, Eindhoven, The Netherlands). With this aim, the Debye-Scherrer method was used $(\mathrm{Cu}-\mathrm{K} \alpha$ radiation of $\lambda=1.5405 \AA)$.

Magnetic properties of the $\left(\gamma-\mathrm{Fe}_{2} \mathrm{O}_{3} / \mathrm{PLGA}\right) / \mathrm{CS}$ particles were investigated at $25.0 \pm 0.5{ }^{\circ} \mathrm{C}$, under the effect of a magnetic field of 0 to $4000 \mathrm{kA} / \mathrm{m}$ (Manics DSM-8 vibrating magnetometer, Toulouse, France). As well, optical visualization of the magnetic 
responsiveness of the (core/shell)/shell NPs to a $400 \mathrm{mT}$ permanent magnet, placed close to the glass vial containing the colloid $(\approx 0.1 \%, w / v)$, was done. These are in-vitro experiments widely used to evaluate the magnetic responsiveness of a nanoparticulate system, as previously defined in the literature [22,32,75-77].

\subsection{Hemocompatibility}

One important aspect to consider when defining the clinical use of a nanoparticulate system is how the colloid interacts with blood, and the consequences, e.g., impact on erythrocytes, coagulation, and complement system. In this study, it was followed a previously described procedure appropriate to nanopharmaceutics $[67,78,79]$. Briefly, blood samples, taken from three healthy adults $(22,26$, and 43 years old), were poured into flasks containing EDTA (before the haemolysis, and platelet activation experiments), or $\mathrm{NaH}_{2}\left(\mathrm{C}_{3} \mathrm{H}_{5} \mathrm{O}(\mathrm{COO})_{3}\right.$ ) (before the complement system activation, and plasma clotting time assays). PBS was the negative control used in the experiments. The $\gamma-\mathrm{Fe}_{2} \mathrm{O}_{3}$ or the $\left(\gamma-\mathrm{Fe}_{2} \mathrm{O}_{3} /\right.$ PLGA)/CS particles were kept in contact with the samples to evaluate their interaction with blood. Validated UV spectrophotometric method was used in the assay which was done in triplicate.

\subsection{In-Vitro Quantification of CDDP Loading}

Evaluation of the amount of antitumour agent loaded to the $\gamma-\mathrm{Fe}_{2} \mathrm{O}_{3} /$ PLGA and $\left(\gamma-\mathrm{Fe}_{2} \mathrm{O}_{3} / \mathrm{PLGA}\right) / \mathrm{CS}$ particles was done in triplicate by UV spectrophotometric determinations of the CDDP molecules remaining in the supernatant after NP centrifugation (60 min and 11,000 rpm) (Centrifuge 5804, Eppendorf Ibérica S.L.U., Madrid, Spain). Considering that quantity was not loaded and the total amount of chemotherapeutic was used, the incorporation of CDDP to the NPs was determined. In these quantifications, contributions to the absorbance of sources other than variations in drug concentration, i.e., PVA, $\mathrm{CH}_{3} \mathrm{COOH}$, and Kolliphor ${ }^{\circledR} \mathrm{P}-188$, were taken into account by subtracting the absorbance of the supernatant produced under the same conditions but without CDDP.

These UV absorption measurements were performed at the maximum absorbance wavelength of this chemotherapeutic (301 nm) (Lambda ${ }^{\mathrm{TM}} 25 \mathrm{UV} /$ Vis spectrophotometer, PerkinElmer Inc., Waltham, MA, USA). Good linearity was observed at this wavelength between absorbance and drug concentration data $(r=0.997)$, and the method was validated and verified for precision, accuracy, and linearity. CDDP incorporation to the magnetopolymeric NPs was calculated in terms of DL (\%) (Equation (2)):

$$
\mathrm{DL}(\%)=\frac{\text { Entrapped CDDP }(\mathrm{mg})}{\mathrm{CDDP}-\text { loaded NPs }(\mathrm{mg})} \times 100
$$

\subsection{In-Vitro Quantification of CDDP Release}

The CDDP release experiments were based on the dialysis bag method $(n=3)$, and they were carried out using the $\left(\gamma-\mathrm{Fe}_{2} \mathrm{O}_{3} / \mathrm{PLGA}\right) / \mathrm{CS}$ particles with the higher DLs $(\approx 15 \%$, see Section 3). The release media were either $\mathrm{C}_{6} \mathrm{H}_{8} \mathrm{O}_{7}-\mathrm{Na}_{2} \mathrm{HPO}_{4}$ or $\mathrm{C}_{6} \mathrm{H}_{8} \mathrm{O}_{7}-\mathrm{NaOH}$ buffers reproducing the $\mathrm{pH}$ of bloodstream $(7.4 \pm 0.1)$ or the acidic microenvironment in tumours $(\mathrm{pH} 5.0 \pm 0.1)$ [80], respectively. These in-vitro drug release media were kept either at the normal human body-temperature (normothermia or euthermia, $37.0 \pm 0.5{ }^{\circ} \mathrm{C}$ ), or at the representative temperature of magnetic hyperthermia-triggered drug release experiments $\left(45.0 \pm 0.5{ }^{\circ} \mathrm{C}\right)$ [81-83]. The latter temperature is also the characteristic maximum hyperthermia temperature of magnetic colloids commonly used as magnetic hyperthermia agents for cancer treatment $[83,84]$.

Before use, the dialysis bags (cut-off of $2000 \mathrm{Da}$, Spectrum ${ }^{\circledR}$ Spectra/Por ${ }^{\circledR} 6$ dialysis membrane tubing, New Brunswick, NJ, USA) were soaked in water at room temperature for $12 \mathrm{~h}$. Then, $2 \mathrm{~mL}$ of the dispersion of CDDP-loaded $\left(\gamma-\mathrm{Fe}_{2} \mathrm{O}_{3} /\right.$ PLGA)/CS NPs (containing $2.5 \mathrm{mg} / \mathrm{mL}$ of chemotherapy agent) were poured into the bag with the two ends fixed by clamps. The dialysis bags were placed in a glass beaker containing $0.1 \mathrm{~L}$ of release medium 
and stirred at $100 \mathrm{rpm}$. At prefixed time intervals, one $\mathrm{mL}$ of the medium was withdrawn for UV spectrophotometric analysis of the CDDP content (at $301 \mathrm{~nm}$ ). An equal volume of the release media, kept also at $37.0 \pm 0.5$ or $45.0 \pm 0.5^{\circ} \mathrm{C}$, was added after sampling to maintain the sink conditions. The same analytical procedure used to determine the DL (\%) was used, and the in-vitro CDDP release was determined by using Equation (3):

$$
\text { CDDP released }(\%)=\frac{\text { Amount of CDDP released }(\mathrm{mg})}{\text { Amount of CDDP loaded to the NPs }(\mathrm{mg})} \times 100
$$

\subsection{In-Vitro Cytotoxicity Assays}

Blank (drug-unloaded) $\left(\gamma-\mathrm{Fe}_{2} \mathrm{O}_{3} /\right.$ PLGA)/CS NPs were tested in human colonic CCD-18 fibroblasts (Scientific Instrumentation Centre, University of Granada, Granada, Spain), and in human colon carcinoma T-84 cells (American Type Culture Collection, Manassas, VA, USA). According to the ISO-10993-5 standard [85], cell viability was tested (in triplicate) by the MTT proliferation assay, determining mitochondrial dehydrogenase activity. Detailed methodology has been described in the literature $[67,79]$. The cells were kept in contact with NP concentrations, ranging from 0.05 to $100 \mu \mathrm{g} / \mathrm{mL}$, for 48 and $72 \mathrm{~h}$ at $37.0 \pm 0.5^{\circ} \mathrm{C}$ in a humidified atmosphere of $5 \% \mathrm{CO}_{2}$ in air (MCO-19AIC(UV) $\mathrm{CO}_{2}$ incubator, Sanyo, Osaka, Japan).

Cytotoxicity of the CDDP-loaded (core/shell)/shell particles against human lung adenocarcinoma A-549 cells (American Type Culture Collection, Manassas, VA, USA) was evaluated by the MTT assay in comparison with the free chemotherapy agent $(n=3)$. The amount of these formulations in contact with the tumour cells ranged from 1 to $20 \mu \mathrm{g} / \mathrm{mL}$ equivalent CDDP concentrations (NP concentrations from $\approx 6.5$ to $130 \mu \mathrm{g} / \mathrm{mL}$ ).

Cells without treatment were used as control to calculate the relative cell viability (RCV, \%) (Equation (4)).

$$
\operatorname{RCV}(\%)=\frac{\text { Optical density of treated cells }}{\text { Optical density of control (untreated) cells }} \times 100
$$

The half maximal inhibitory concentration $\left(\mathrm{IC}_{50}\right)$ values were estimated by a non-linear regression analysis (GraphPad Prism 9.1.0, GraphPad Software Inc., La Jolla, CA, USA) [86,87].

\subsection{Statistical Analysis}

The IBM ${ }^{\circledR}$ SPSS $^{\circledR}$ Statistics 26.0 software package (IBM Corporation, New York, NY, USA) was used to that aim. Student's t-test was done to compare results considering $95 \%$ confidence interval. The experimental data were expressed as mean value $\pm \mathrm{SD}$, and the differences were considered to be statistically significant at $p<0.05$, or highly significant at $p<0.01$.

\section{Results and Discussion}

On the basis of the experimental data collected in this Section, it is discussed how the $\left(\gamma-\mathrm{Fe}_{2} \mathrm{O}_{3} /\right.$ PLGA)/CS (core/shell)/shell NPs are characterized by an appropriate size and blood compatibility for intravenous administration, also probably by stealth properties; and, more interestingly, by adequate magnetic-, pH-, and heat (hyperthermia)-sensitivities. All these characteristics could make the nanocomposites an interesting nanocarrier for CDDP: site-specific delivery of the antitumour agent could be considerably optimized, reaching therapeutic levels inside the malignant cells. Of course, defining the real possibilities of these CDDP-loaded nanostructures against lung cancer will only be possible if additional in-vitro tests and, more significantly, experiments in tumour-bearing are done.

\subsection{Characterization of the Nanoparticulate Systems}

Mean diameter (and PdI) of $\gamma-\mathrm{Fe}_{2} \mathrm{O}_{3}$ nuclei, pure CS particles, and $\left(\gamma-\mathrm{Fe}_{2} \mathrm{O}_{3} / \mathrm{PLGA}\right)$ NPs were: $10.2 \pm 2.1,364.1 \pm 15.3$, and $291.2 \pm 1.8 \mathrm{~nm}$, respectively. The methodology of preparation of the $\left(\gamma-\mathrm{Fe}_{2} \mathrm{O}_{3} /\right.$ PLGA) $/ \mathrm{CS}$ NPs reported adequate sizes $(332.1 \pm 82.1 \mathrm{~nm})$, and PPs $(\approx 50 \%)$. These diameters are compatible with parenteral administration and could favour NP accumulation at the cancer site (gaps of up to $\approx 600 \mathrm{~nm}$ between endothelial 
cells of the vasculature) $[22,88]$. Some studies have reported that particles up to $400 \mathrm{~nm}$ may extravasate into the tumor tissue, taking advantage of the EPR effect [89-91]. For instance, CDDP-loaded particles with sizes from 300 to $500 \mathrm{~nm}$ have been described to reach the cancer site, inhibiting tumour growth after intravenous administration [60,92]. In addition, early plasma clearance could be minimized thanks to the stealth property that CS may provide to the (core/shell)/shell particles, and to their positive surface electrical charge ( $\zeta$ value: $23.6 \pm 0.3 \mathrm{mV}$ ) $[45,93]$. These positive $\zeta$ values may further promote NP internalization by the (negatively charged) cancer cell $[49,94]$.

Regarding the short-term evaluation of the stability of these nanocomposites, data in Table 1 illustrates the absence of relevant changes in the size (and PdI) and surface electrical charge of the NPs. Therefore, it could be postulated that no particle aggregation will occur after one month of storage at room temperature in water. The PDI values were $\leq 0.5$ during the study, similarly to what has been previously described for PLGA-based NPs surface functionalized with CS [95-97]. Such PDI data could be considered acceptable and characteristic of relatively homogeneous NP dispersions [98,99].

Table 1. Particle diameter (nm), PdI, and $\zeta$ values $(\mathrm{mV})$ of the (core/shell)/shell NPs as a function of time (days). Data are expressed as means \pm SDs of triplicate experiments.

\begin{tabular}{cccccc}
\hline Time & Day 0 & Day 1 & Day 7 & Day 14 & Day 30 \\
\hline Size (nm) & $332.1 \pm 82.1$ & $329.9 \pm 168.3$ & $333.8 \pm 105.3$ & $321.5 \pm 97.8$ & $334.9 \pm 71.4$ \\
\hline PdI & $0.375 \pm 0.006$ & $0.422 \pm 0.075$ & $0.403 \pm 0.036$ & $0.289 \pm 0.052$ & $0.412 \pm 0.077$ \\
\hline$\zeta(\mathbf{m V})$ & $23.6 \pm 0.3$ & $17.3 \pm 0.7$ & $23.3 \pm 0.5$ & $14.7 \pm 1.8$ & $26.3 \pm 0.4$ \\
\hline
\end{tabular}

No significant effect on size was observed when the $\left(\gamma-\mathrm{Fe}_{2} \mathrm{O}_{3} / \mathrm{PLGA}\right) / \mathrm{CS}$ NPs were kept in contact with BSA (34, and $54 \mathrm{mg} / \mathrm{mL}$ concentrations in PBS), being the particle diameter and $\mathrm{PdI}$ values $\approx 340 \mathrm{~nm}$ and $\approx 0.335$, respectively. That negligible effect could be attributed to the hydrophilic nature of the CS coating which could minimize protein corona formation and particle aggregation [46,47].

HRTEM (Figure 2a), HAADF-STEM (Figure 2b), and ABF-STEM (Figure 2c) photographs demonstrated the satisfactory embedment of the $\gamma-\mathrm{Fe}_{2} \mathrm{O}_{3}$ nuclei into the polymeric nanostructure. Particle aggregation observed in Figure 2 could be the consequence of the preparation of the samples by drying for the EM visualizations. This is a phenomenon previously described in CS-based magnetic nanocomposites $[100,101]$ that determined the impossibility of identifying the shape of a single NP. On the other hand, the homogeneous distribution of these iron oxide nanocores within the particle matrix is visible in the EDX Fe element mapping of the ( $\gamma$ - $\mathrm{Fe}_{2} \mathrm{O}_{3} /$ PLGA)/CS NPs (Figure 2d). Uniform coverage of the $\gamma-\mathrm{Fe}_{2} \mathrm{O}_{3} /$ PLGA particles by the CS shell can be postulated from the EDX N element mapping of these (core/shell)/shell NPs (Figure 2e). Additionally, EDX analyses confirmed the presence of the $\mathrm{Fe}, \mathrm{C}, \mathrm{N}$, and $\mathrm{O}$ elements for the nanocomposites (Figure 3). The $\mathrm{Fe}$ element arose from the $\gamma-\mathrm{Fe}_{2} \mathrm{O}_{3}$ cores and was only detected when the EDX spectrum was taken from the centre of the (core/shell)/shell particles (Figure 3a). On the opposite, the N element (from the CS shell) was identified in any EDX spectra taken of the NPs (Figure $3 \mathrm{a}, \mathrm{b}$ ), thus confirming the homogeneous disposition of CS onto the core/shell nanostructure. These observations established the formation of the $\left(\gamma-\mathrm{Fe}_{2} \mathrm{O}_{3} / \mathrm{PLGA}\right) / \mathrm{CS}$ (core/shell)/shell nanostructure. Finally, the existence of the $\mathrm{Cu}$ and $\mathrm{Si}$ elements in the EDX analysis could arise from the use of copper-based grids [32] and the production of a secondary fluorescence by the fluorescence detector [102]. 


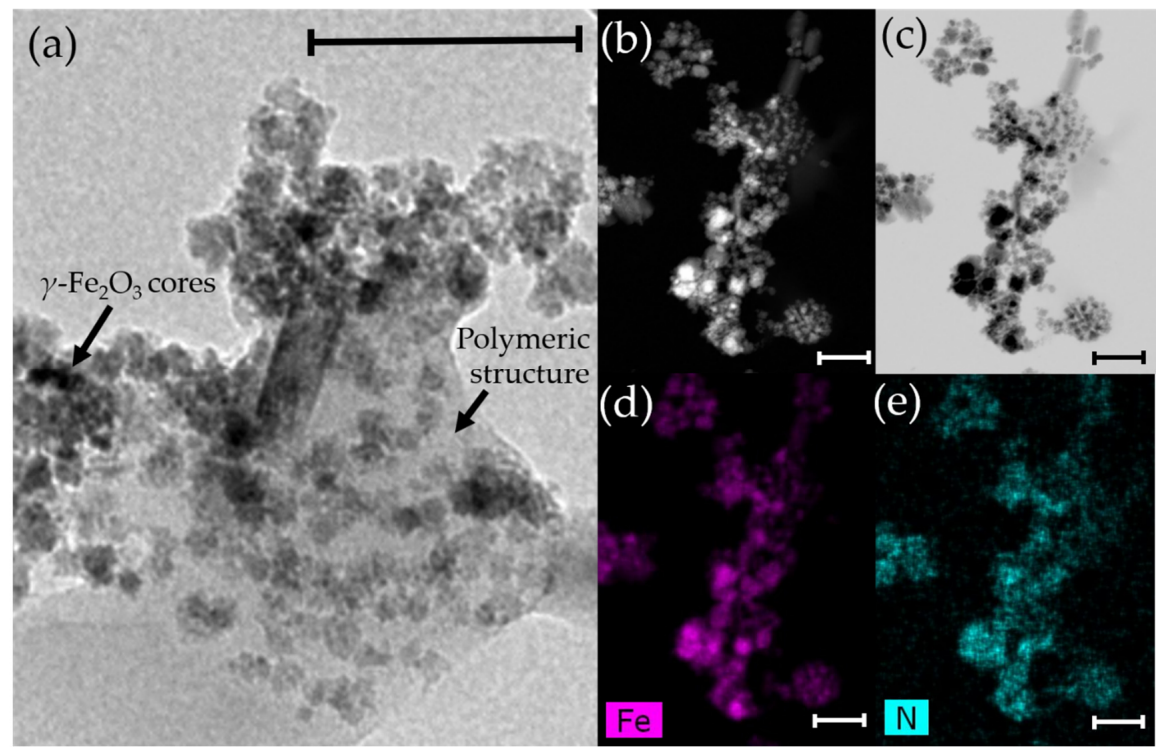

Figure 2. (a) HRTEM, (b) HAADF-STEM, and (c) ABF-STEM images of the $\left(\gamma-\mathrm{Fe}_{2} \mathrm{O}_{3} /\right.$ PLGA)/CS nanocomposites; EDX mapping analysis of the (d) Fe and (e) N elements of the sample in (b,c). Bar lengths: $100 \mathrm{~nm}$. The arrows in (a) mark the $\gamma-\mathrm{Fe}_{2} \mathrm{O}_{3}$ cores inside the polymeric structure.
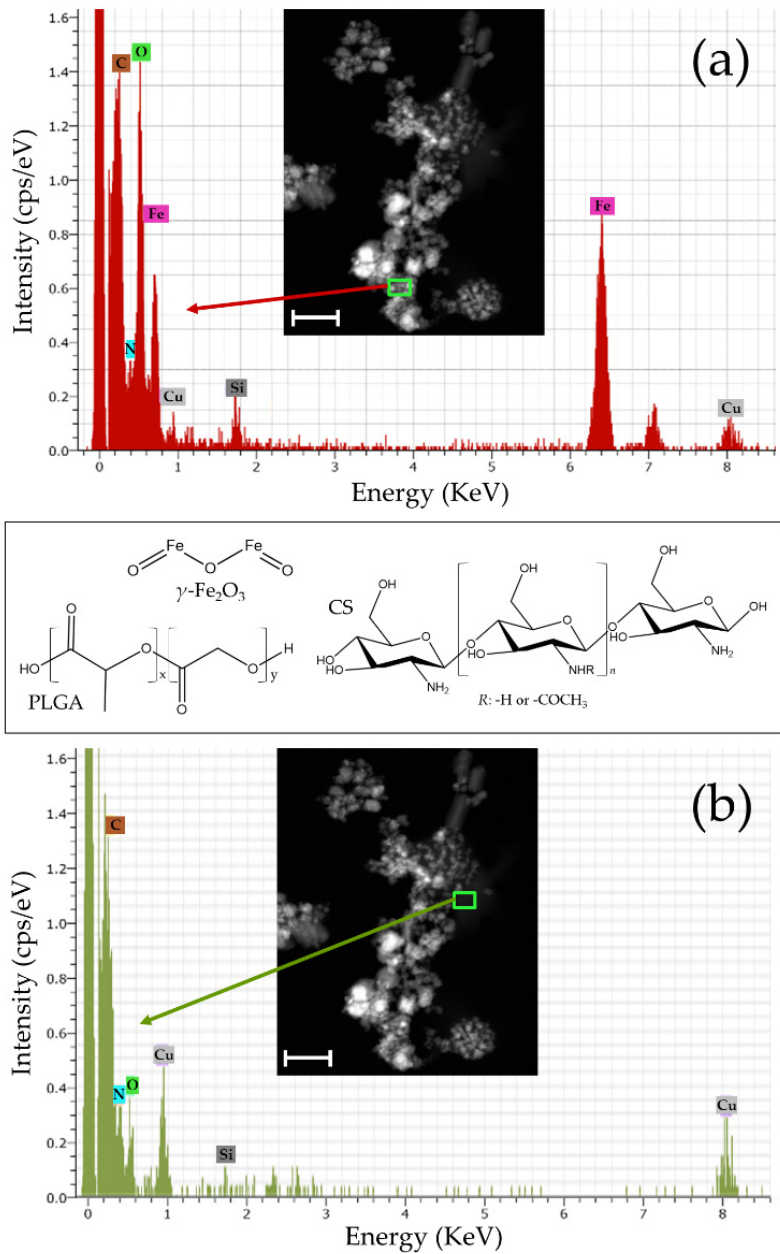

Figure 3. EDX spectra of: (a) the centre and (b) flank of the (core/shell)/shell NPs. Insets: HAADFSTEM images of these nanocomposites (bar lengths: $100 \mathrm{~nm}$ ), and chemical structures of $\gamma-\mathrm{Fe}_{2} \mathrm{O}_{3}$, PLGA and CS. 
Electrophoretic characterization of the colloids was then done to define qualitatively the surface disposition of CS onto the $\left(\gamma-\mathrm{Fe}_{2} \mathrm{O}_{3} / \mathrm{PLGA}\right)$ (core/shell) particles. Concretely, it was determined the surface electrical charge ( $\zeta$ values) of the $\gamma-\mathrm{Fe}_{2} \mathrm{O}_{3} / \mathrm{PLGA}, \mathrm{CS}$, and $\left(\gamma-\mathrm{Fe}_{2} \mathrm{O}_{3} / \mathrm{PLGA}\right) / \mathrm{CS}$ NPs at predetermined ionic strengths $\left(\mathrm{KNO}_{3}\right.$ molar concentrations) and $\mathrm{pH} \approx 6$ (the natural $\mathrm{pH}$ of the colloids). Similarities between the $\zeta$ values of the CS and $\left(\gamma-\mathrm{Fe}_{2} \mathrm{O}_{3} / \mathrm{PLGA}\right) / \mathrm{CS}$ particles, and how different they were from those of the $\gamma-\mathrm{Fe}_{2} \mathrm{O}_{3} /$ PLGA NPs are plotted in Figure 4a. The negative surface charge of the $\gamma-\mathrm{Fe}_{2} \mathrm{O}_{3}$ /PLGA particles may come from ionized weak acid groups, probably carboxylicend groups of PLGA $[103,104]$. On the opposite, the positive $\zeta$ values of pure CS and $\left(\gamma-\mathrm{Fe}_{2} \mathrm{O}_{3} /\right.$ PLGA)/CS NPs could come from the residual amino groups existing in the chemical structure of CS $[42,105]$. Finally, the decrease in the absolute values of $\zeta$ described by the NPs at the larger ionic strengths should be the consequence of the classical double-layer compression mechanism $[106,107]$. It can be observed in Figure 4a how the $\zeta$-ionic strength trend of the $\left(\gamma-\mathrm{Fe}_{2} \mathrm{O}_{3} /\right.$ PLGA $) / C S$ NPs was dominated by the CS shell, probably being that the consequence of the effective CS coating of the $\left(\gamma-\mathrm{Fe}_{2} \mathrm{O}_{3} /\right.$ PLGA) particles. Finally, if the electrophoretic data in Figure 4a is considered, a mechanism could be postulated to explain the generation of the (core/shell)/shell NPs: accumulation of CS onto the $\gamma-\mathrm{Fe}_{2} \mathrm{O}_{3} /$ PLGA surface may occur thanks to attractive interactions between the negatively charged core/shell particles and the positively charged CS matrix [52,108].
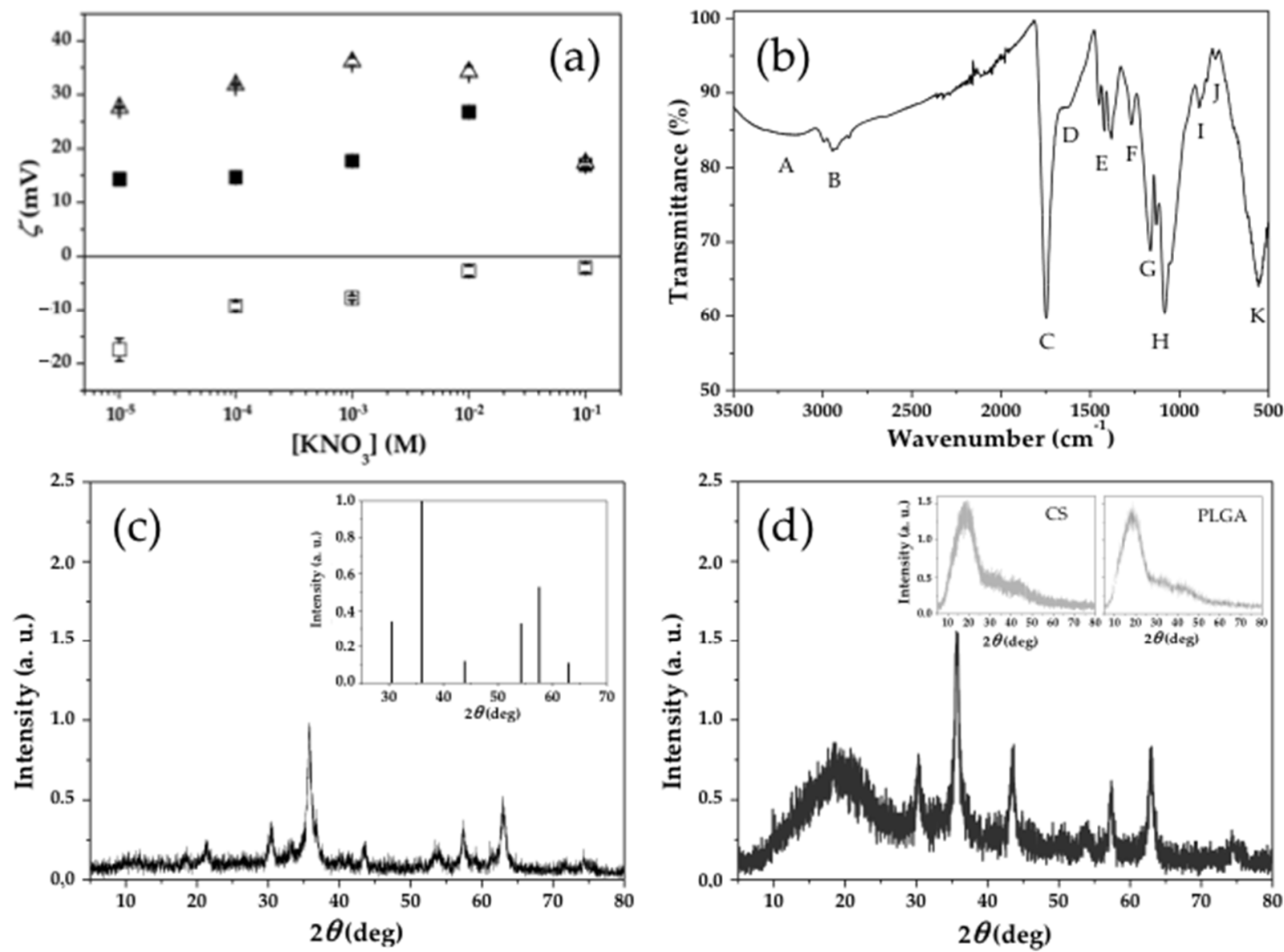

Figure 4. (a) Zeta potential $(\zeta, \mathrm{mV})$ of $(\square) \gamma-\mathrm{Fe}_{2} \mathrm{O}_{3} /$ PLGA NPs, $(\Delta)$ CS NPs, and ( $\left.\square\right)\left(\gamma-\mathrm{Fe}_{2} \mathrm{O}_{3} /\right.$ PLGA)/CS NPs as a function of the molar concentration of $\mathrm{KNO}_{3}$, at $\mathrm{pH} \approx 6$. Data is presented as mean value $\pm \mathrm{SD}(n=9)$. (b) Infrared spectra of the (core/shell)/shell NPs. (c) X-ray diffractogram of the $\gamma-\mathrm{Fe}_{2} \mathrm{O}_{3}$ particles. Inset: American Society for Testing and Materials (ASTM) pattern for $\gamma$ - $\mathrm{Fe}_{2} \mathrm{O}_{3}$. (d) X-ray diffractogram of the $\left(\gamma-\mathrm{Fe}_{2} \mathrm{O}_{3} /\right.$ PLGA) /CS NPs. Inset: X-ray diffractograms of the CS particles, and PLGA particles. The intensity is expressed in arbitrary units (a. u.). 
The infrared spectra of the $\left(\gamma-\mathrm{Fe}_{2} \mathrm{O}_{3} /\right.$ PLGA $) / C S$ NPs is represented in Figure $4 \mathrm{~b}$. All the characteristics bands of the polymers (CS and PLGA) were present in the spectrum of these magnetopolymeric particles, hence demonstrating that the shell observed in Figure 2 corresponded well to the PLGA and CS shells onto the $\gamma-\mathrm{Fe}_{2} \mathrm{O}_{3}$ nuclei. Chemical groups identified in the spectra were: (A) overlapped stretching vibrations from $\mathrm{N}-\mathrm{H}$ and $\mathrm{O}-\mathrm{H}$ bonds (at $\approx 3400 \mathrm{~cm}^{-1}$ ) [109-111]; (B) C-H bond stretching vibration of $-\mathrm{CH}$, $-\mathrm{CH}_{2}$, and $-\mathrm{CH}_{3}$ groups (at $\approx 2850 \mathrm{~cm}^{-1}$ ) $[109,110,112] ;(\mathrm{C}) \mathrm{C}=\mathrm{O}$ bond stretching vibration of a carboxylic acid (at $\approx 1750 \mathrm{~cm}^{-1}$ ), probably from the PLGA shell [111,113,114]; (D) $\mathrm{C}=\mathrm{O}$ bond stretching vibration of an amide group, presumably from the CS coating $\left(\approx 1630 \mathrm{~cm}^{-1}\right)[110,112,115]$; $(\mathrm{E})$ asymmetric $\mathrm{CH}_{2}$ bending vibration $($ at $\approx 1450$ and $\approx 1380 \mathrm{~cm}^{-1}$ ) $[110,112,113]$, and $\mathrm{O}-\mathrm{H}$ bending vibration, probably from the carboxylic group in the PLGA shell (at $\approx 1420 \mathrm{~cm}^{-1}$ ) [104]; (F) C-O bond stretching vibrations from a $-\mathrm{OH}$ group (at $\approx 1280 \mathrm{~cm}^{-1}$ ) [116]; (G) C-O bond stretching vibration from the carboxylic group in PLGA (at $\approx 1160 \mathrm{~cm}^{-1}$ ) [104,116]; $(\mathrm{H}) \mathrm{C}-\mathrm{O}-\mathrm{C}$ bond stretching vibration from PLGA (at $\approx 1130$ and $\approx 1080 \mathrm{~cm}^{-1}$ ) [97,104,112]; (I) medium band characteristic of alkanes (at $\approx 890 \mathrm{~cm}^{-1}$ ) [117]; (J) CH rocking vibration characteristic of $-\mathrm{CH}$ long chains $\left(\right.$ at $\approx 800 \mathrm{~cm}^{-1}$ ) [104,117]; and, $(\mathrm{K}) \mathrm{Fe}-\mathrm{O}$ bond vibration from pure iron oxide NPs (at $\approx 560 \mathrm{~cm}^{-1}$ ) [104,118,119].

The X-ray diffraction patterns of $\gamma-\mathrm{Fe}_{2} \mathrm{O}_{3}$, and $\left(\gamma-\mathrm{Fe}_{2} \mathrm{O}_{3} /\right.$ PLGA)/CS NPs are plotted in Figure 4c,d, respectively. They coincided with the American Society for Testing and Materials (ASTM) pattern of $\gamma-\mathrm{Fe}_{2} \mathrm{O}_{3}$ (inset of Figure 4c) (ASTM No. 24-81). The experimental data suggested that, after complete inclusion into the PLGA and CS shells, the $\gamma-\mathrm{Fe}_{2} \mathrm{O}_{3}$ nuclei maintained a high crystallinity and mineralogical purity. These are properties beneath an appropriate magnetic responsiveness and a superparamagnetic behaviour [22]. $2 \theta$ values of the $\gamma-\mathrm{Fe}_{2} \mathrm{O}_{3}$ nanocores existing into the $\left(\gamma-\mathrm{Fe}_{2} \mathrm{O}_{3} / \mathrm{PLGA}\right) / \mathrm{CS}$ nanostructure were $29.89^{\circ}, 35.17^{\circ}, 43.43^{\circ}, 53.92^{\circ}, 56.87^{\circ}$, and $63.12^{\circ}$, and they may be assigned to the (2 20$),(31$ 1), (4 0 0), (4 2 2) , (5 1 1 1), and (4 4 0) planes of these iron oxides, respectively [120-122]. In addition, broad diffraction peaks were observed for CS and PLGA particles at $2 \theta$ values $\approx 19.90^{\circ}$ and $\approx 18.36^{\circ}$, respectively (insets to Figure $4 \mathrm{~d}$ ). The former peak would be indexed to the (lllll 110 plane that is characteristic of crystalline chitin [123-125], while the diffraction peak observed for PLGA NPs could have come from the amorphous phase of PLGA [126-128]. These broad peaks were integrated in the X-ray diffractogram of the $\left(\gamma-\mathrm{Fe}_{2} \mathrm{O}_{3} / \mathrm{PLGA}\right) / \mathrm{CS}$ NPs $\left(2 \theta\right.$ value $\left.\approx 18.57^{\circ}\right)$, probably a confirmation of the efficiency of the preparation procedure in generating that (core/shell)/shell nanostructure.

The first magnetization curve of the $\left(\gamma-\mathrm{Fe}_{2} \mathrm{O}_{3} / \mathrm{PLGA}\right) / \mathrm{CS}$ NPs, shown in Figure 5a, characterized the appropriate magnetic responsiveness of this magnetic colloid. Initial susceptibility and saturation magnetization values of the (core/shell)/shell particles were $(0.077 \pm 0.003) \times 10^{-3} \mathrm{~m}^{3} / \mathrm{Kg}$ and $5.03 \pm 0.37 \mathrm{Am}^{2} / \mathrm{Kg}$, respectively. That adequate magnetic responsive behaviour was further qualitatively confirmed by visual observation of the colloid under exposure to a permanent magnet (Figure 5b): complete magnetic attraction of the NPs toward the $400 \mathrm{mT}$ magnet occurred in $120 \mathrm{~s}$. However, in-vivo experiments should be performed to define if this magnetic responsiveness could favour the accumulation of the $\left(\gamma-\mathrm{Fe}_{2} \mathrm{O}_{3} /\right.$ PLGA $) / C S$ particles at a targeted site. 


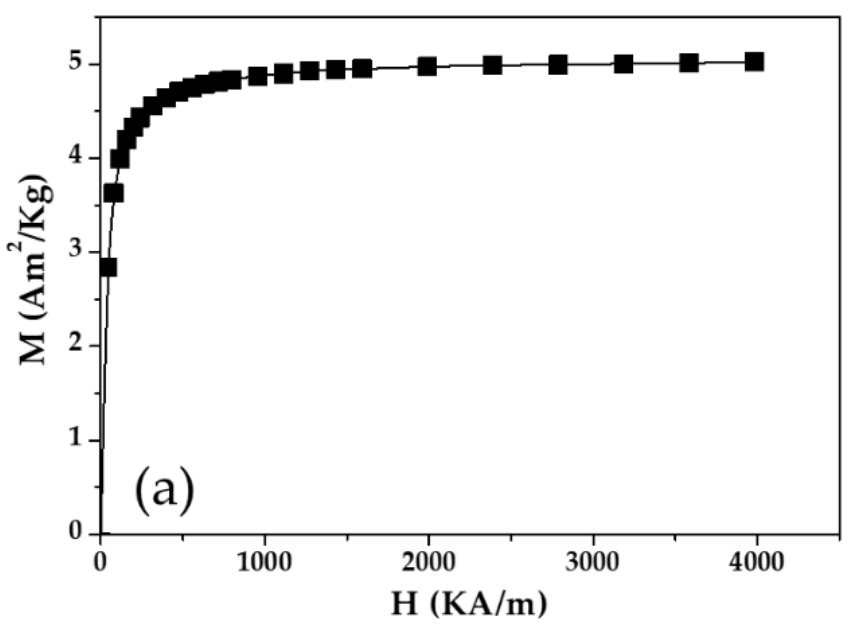

(b)

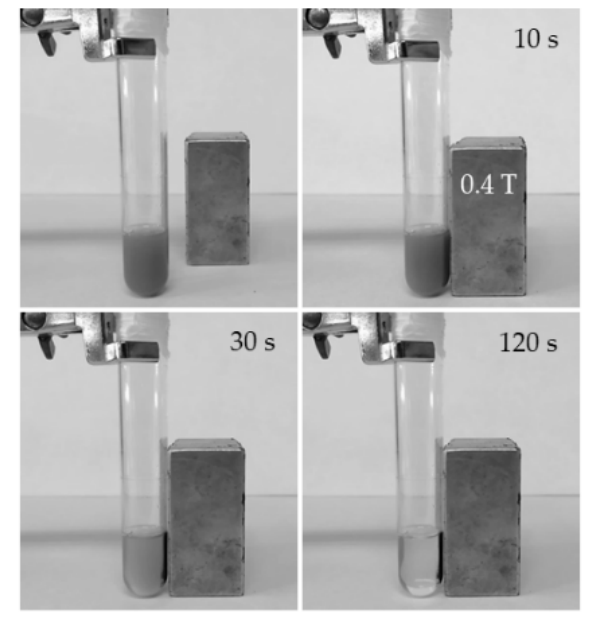

Figure 5. (a) First magnetization curve of the (core/shell)/shell NPs. (b) Visual observation of the colloid $(0.1 \%, w / v)$ under the influence of $0.4 \mathrm{~T}$ permanent magnet, located close to the right lateral flat surface of the glass vial.

\subsection{Cytotoxicity and Blood Compatibility}

Data from the evaluation of the cytotoxicity of $\left(\gamma-\mathrm{Fe}_{2} \mathrm{O}_{3} /\right.$ PLGA)/CS NPs in normal CCD-18 and tumour T-84 cells are represented in Figure 6, which illustrates how viability of both cell lines was not altered by these (core/shell)/shell particles, even when the NP concentration was increased from 0.05 to $100 \mu \mathrm{g} / \mathrm{mL}$. According to ISO-10993-5 [85], the RCV (\%) values plotted in Figure 6 could be considered to be non-toxic. Additionally, growth of cells kept in contact with non-cytotoxic blank (drug-unloaded) NPs has been described to be not hindered, even at high concentrations [129-131]; as a result, proliferation can continue under in-vitro conditions. On the other hand, experimental results from the ex-vivo hemocompatibility assays of $\gamma-\mathrm{Fe}_{2} \mathrm{O}_{3}$ and $\left(\gamma-\mathrm{Fe}_{2} \mathrm{O}_{3} /\right.$ PLGA)/CS particles demonstrated a negligible effect on haemolysis, platelet activation, complement system activation, and plasma clotting time was observed (Table 2). Therefore, taking into account the results from Figure 6 and Table 2, it could be postulated that the $\left(\gamma-\mathrm{Fe}_{2} \mathrm{O}_{3} / \mathrm{PLGA}\right) / \mathrm{CS}$ NPs are characterized by an adequate biocompatibility and safety for drug delivery purposes, being suitable for parenteral administration. 


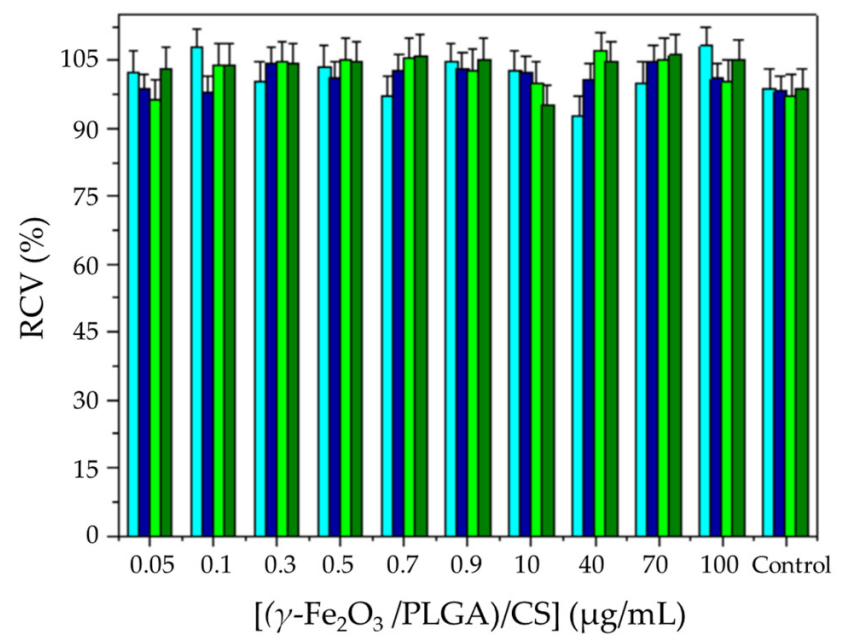

Figure 6. In-vitro cytotoxicity (RCV, \%) of the $\left(\gamma-\mathrm{Fe}_{2} \mathrm{O}_{3} / \mathrm{PLGA}\right) / \mathrm{CS}$ NPs in CCD-18 cells at $48 \mathrm{~h}$ (blue columns) and $72 \mathrm{~h}$ (green columns), and in T-84 cells at $48 \mathrm{~h}$ (dark blue columns) and $72 \mathrm{~h}$ (dark green columns). These cell lines were kept in contact with NP concentrations, ranging from 0.05 to $100 \mu \mathrm{g} / \mathrm{mL}$.

Table 2. Effect of the $\gamma-\mathrm{Fe}_{2} \mathrm{O}_{3}$, and $\left(\gamma-\mathrm{Fe}_{2} \mathrm{O}_{3} /\right.$ PLGA)/CS NPs on haemolysis (\%), complement activation (C3a release: $\mathrm{C} 3 a$ desArg, $\mathrm{ng} / \mathrm{mL}$ ), platelet activation (sP-selectin release, $\mathrm{ng} / \mathrm{mL}$ ), and plasma recalcification time $\left(\mathrm{T}_{1 / 2} \max , \mathrm{min}\right)$. Data is indicated as means $\pm \mathrm{SDs}(n=3)$.

\begin{tabular}{cccc}
\hline & $\gamma-\mathrm{Fe}_{2} \mathrm{O}_{3} \mathrm{NPs}$ & $\begin{array}{c}\left(\gamma-\mathrm{Fe}_{2} \mathrm{O}_{3} / \mathrm{PLGA}\right) / \mathrm{CS} \\
\mathrm{NPs}\end{array}$ & Control (PBS Solution) \\
\hline Haemolysis (\%) & $1.6 \pm 0.1$ & $2.5 \pm 0.4$ & 0 \\
\hline C3a desArg (ng/mL) & $296 \pm 3$ & $309 \pm 8$ & $290 \pm 9$ \\
\hline $\begin{array}{c}\text { sP-selectin release } \\
(\mathbf{n g} / \mathbf{m L})\end{array}$ & $105 \pm 6$ & $117 \pm 5$ & $99 \pm 6$ \\
\hline $\mathbf{T}_{\mathbf{1} / \mathbf{2} \text { max }}(\mathbf{m i n})$ & $14.1 \pm 0.7$ & $13.8 \pm 1.2$ & $12.2 \pm 0.9$ \\
\hline
\end{tabular}

\subsection{CDDP Loading}

The conditions fixed to prepare the CDDP-loaded $\gamma-\mathrm{Fe}_{2} \mathrm{O}_{3} / \mathrm{PLGA}$ NPs tried to minimize the escape of this hydrophilic drug [132] from mechanical trapping into the hydrophobic PLGA matrix [104]. It has been previously determined the very rapid precipitation of the polymer matrix, just upon contacting the $\mathrm{H}_{2} \mathrm{O}$ phase, when PLGA NPs are prepared by the nanoprecipitation solvent evaporation technique $[103,133]$. As a consequence, mechanical trapping of the drug inside that polymer network would be facilitated [134]. Complementarily, stabilizing agents, e.g., poloxamers, PVA, may induce the opening of the polymer chains to create a space within the PLGA matrix where the drug could be incorporated $[133,135]$. Furthermore, CDDP incorporation to the PLGA matrix could be the consequence of electrostatic attractions between drug molecules, positively charged when the $-\mathrm{NH}$ group is protonated, and the negatively charged polymer $(\approx-10 \mathrm{mV}$ at natural $\mathrm{pH}$ 6). Electrostatic repulsions between the positively charged CDDP molecules and the positively charged $\gamma-\mathrm{Fe}_{2} \mathrm{O}_{3}$ nuclei $(\approx+20 \mathrm{mV}$ at natural $\mathrm{pH} 6)$ of these nanostructures may prevent drug adsorption onto these iron oxides.

CDDP loading values to the $\gamma-\mathrm{Fe}_{2} \mathrm{O}_{3} /$ PLGA, and $\left(\gamma-\mathrm{Fe}_{2} \mathrm{O}_{3} /\right.$ PLGA)/CS nanocomposites are compiled in Table 3. As expected, drug concentration positively influenced CDDP absorption into the core/shell nanostructure, while no relevant modification of the DL (\%) values was observed when the $\gamma-\mathrm{Fe}_{2} \mathrm{O}_{3} /$ PLGA particles were surface coated with CS. In addition, CDDP incorporation to the $\left(\gamma-\mathrm{Fe}_{2} \mathrm{O}_{3} / \mathrm{PLGA}\right) / \mathrm{CS}$ particles reported greater DL values $(\approx 15 \%)$ than those previously ascribed to non-magnetic PLGA/CSbased particles (DL $\approx 9 \%$ ) [49]. Finally, particle diameter and surface electrical charge of the 
(core/shell)/shell particles did not vary when loaded with the chemotherapy agent: $\approx 325 \mathrm{~nm}$ and $\approx+23 \mathrm{mV}$, respectively. The great similarity between the $\zeta$ values of the non-loaded and the CDDP-loaded $\left(\gamma-\mathrm{Fe}_{2} \mathrm{O}_{3} / \mathrm{PLGA}\right) / \mathrm{CS}$ particles may suggest an efficient absorption of the CDDP molecules into the nanocomposites.

Table 3. Loading of CDDP (DL, \%) to the $\gamma-\mathrm{Fe}_{2} \mathrm{O}_{3} / \mathrm{PLGA}$, and $\left(\gamma-\mathrm{Fe}_{2} \mathrm{O}_{3} / \mathrm{PLGA}\right) / \mathrm{CS}$ particles.

\begin{tabular}{ccc}
\hline Nanoparticulate System & [CDDP] $(\mu \mathrm{g} / \mathrm{mL})$ & DL $(\%)$ \\
\hline & 3 & $0.021 \pm 0.003$ \\
$\gamma-\mathrm{Fe}_{2} \mathrm{O}_{3} /$ PLGA & 15 & $0.212 \pm 0.079$ \\
& 30 & $0.995 \pm 0.163$ \\
& 150 & $5.945 \pm 0.364$ \\
$\left(\gamma-\mathrm{Fe}_{2} \mathrm{O}_{3} /\right.$ PLGA $) / \mathrm{CS}$ & 300 & $16.057 \pm 2.359$ \\
\hline
\end{tabular}

\subsection{CDDP Release}

The $\mathrm{pH}$-responsive CDDP release from the $\left(\gamma-\mathrm{Fe}_{2} \mathrm{O}_{3} / \mathrm{PLGA}\right) / \mathrm{CS}$ NPs was evaluated at $37.0 \pm 0.5^{\circ} \mathrm{C}$ by using release media reproducing either the $\mathrm{pH} \approx 7.4$ of bloodstream or the acidic microenvironment in tumours $(\mathrm{pH} \approx 5$ ) (Figure 7). A biphasic drug release profile was identified, which is characteristic of PLGA-based [58,67] and CS-based [42,60] particles, and has been previously proposed for PLGA/CS (core/shell) nanostructures loaded with Paclitaxel [49], and Itraconazole [136]. In detail, the process started with an early-time burst drug release, taking place in $\approx 6 \mathrm{~h}$ (up to $\approx 21 \%$ at $\mathrm{pH} 7.4$, and $\approx 39 \%$ at $\mathrm{pH}$ 5.0). The remaining chemotherapeutic was then released slowly during around the next $154 \mathrm{~h}$ at $\mathrm{pH} 7.4$, and $66 \mathrm{~h}$ at $\mathrm{pH}$ 5.0. Such a biphasic CDDP release profile could be attributed to drug diffusion through the PLGA/CS architecture in the initial stage and to degradation/erosion of these polymer matrices during the final phase of drug release $[50,67,137]$, and may further suggest that the major proportion of CDDP molecules was entrapped efficiently into the PLGA shell. Significantly, the pH-responsive CDDP release behaviour was identified in Figure $7: \approx 1.4$-fold faster drug release at $\mathrm{pH} 5.0$ compared to $\mathrm{pH} 7.4(p<0.05)$. In comparison with blood, the rapid drug release at the acidic intratumoural $\mathrm{pH}$ may be the consequence of the higher solubility of CS at lower $\mathrm{pH}$ values [42,43] and the accelerated degradation of PLGA by increased hydrolysis of the backbone ester linkages in its chemical structure [36,37]. The existence of hydrophilic CS shell onto the PLGA matrix could enhance the interaction of the NP with the acidic aqueous medium, thus facilitating a faster degradation of PLGA by hydrolysis and, consequently, the more rapid CDDP release compared to what occurred at the $\mathrm{pH} 7.4$ of bloodstream [36].

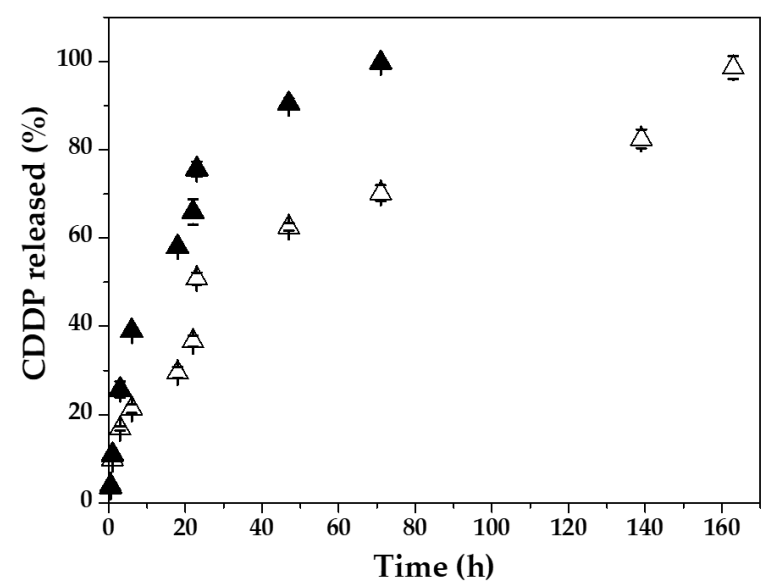

Figure 7. In-vitro release of CDDP (\%) from the $\left(\gamma-\mathrm{Fe}_{2} \mathrm{O}_{3} / \mathrm{PLGA}\right) / \mathrm{CS}$ (core/shell)/shell NPs as a function of the incubation time $(\mathrm{h})$ at $37.0 \pm 0.5^{\circ} \mathrm{C}$, and $\mathrm{pH} 7.4 \pm 0.1(\Delta)$ or $\mathrm{pH} 5.0 \pm 0.1(\boldsymbol{\Delta})$. Data is presented as mean value $\pm \mathrm{SD}(n=3)$. 
The in-vitro CDDP release was considerably augmented when the NPs were kept at the temperature commonly established in magnetic hyperthermia to trigger drug release $\left(45.0 \pm 0.5^{\circ} \mathrm{C}\right)[81-83,138]$. At this temperature, CDDP release was a very rapid process (Figure 8), decelerated when the (core/shell)/shell particles were kept at the physiological $\mathrm{pH}$ of 7.4. Concretely, drug release was completed in $\approx 10 \mathrm{~h}$ at $\mathrm{pH} 7.4$, and in $\approx 6 \mathrm{~h}$ at $\mathrm{pH}$ 5.0. The fast CDDP release from the $\left(\gamma-\mathrm{Fe}_{2} \mathrm{O}_{3} / \mathrm{PLGA}\right) / \mathrm{CS}$ NPs could be resulting from both the enhanced permeability toward water and solutes displayed by the PLGA shell at temperatures over the $T_{\mathrm{g}}$ [39] and the heat-mediated degradation of PLGA [40].

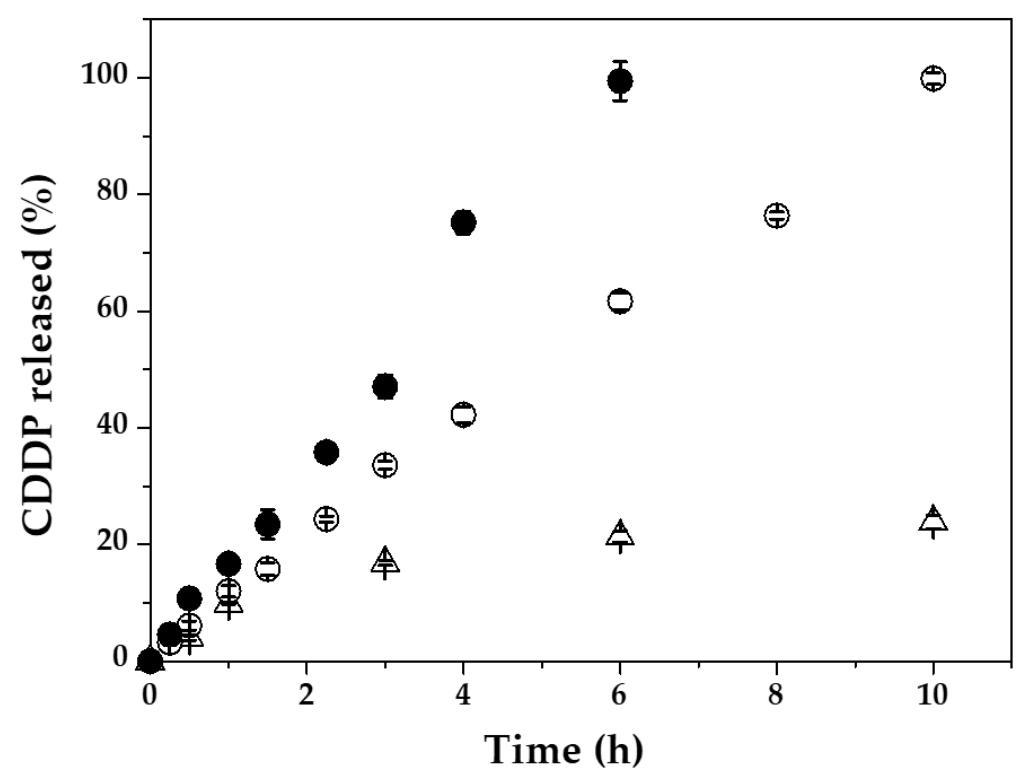

Figure 8. In-vitro release of CDDP (\%) from the $\left(\gamma-\mathrm{Fe}_{2} \mathrm{O}_{3} / \mathrm{PLGA}\right) / \mathrm{CS}$ (core/shell)/shell NPs as a function of the incubation time (h) at $\mathrm{pH} 7.4 \pm 0.1$ and $37.0 \pm 0.5^{\circ} \mathrm{C}(\Delta), \mathrm{pH} 7.4 \pm 0.1$ and $45.0 \pm 0.5^{\circ} \mathrm{C}(\bigcirc)$, and $\mathrm{pH} 5.0 \pm 0.1$ and $45.0 \pm 0.5^{\circ} \mathrm{C}(\bullet)$.

Taking into account the data in the Figures 7 and 8 , it could be postulated that the $\left(\gamma-\mathrm{Fe}_{2} \mathrm{O}_{3} /\right.$ PLGA)/CS particles can display a $\mathrm{pH}$ - and heat-responsive CDDP release behaviour, generating a $\approx 4.7$-fold faster drug release at $\mathrm{pH} 5.0$ and $45^{\circ} \mathrm{C}$ compared to physiological conditions $\left(\mathrm{pH} 7.4\right.$ and $\left.37^{\circ} \mathrm{C}\right)(p<0.05)$. This value was estimated at the $6 \mathrm{~h}$ time point: the moment when all the drug was released at $\mathrm{pH} 5.0$ and $45{ }^{\circ} \mathrm{C}$, while only $\approx 21 \%$ of CDDP was released at $\mathrm{pH} 7.4$ and $37^{\circ} \mathrm{C}$. Finally, and taking into account the data plotted in the Figures 5 and 7, the CS-decorated particles could be considered magnetic-, pH- and heat (hyperthermia)-responsive nanostructures probably facilitating in vivo the selective accumulation of CDDP molecules into the tumour interstitium or even intracellularly (inside the lysosomes of malignant cells after cellular uptake) [139-141].

\subsection{Cytotoxicity against Human Lung Adenocarcinoma A-549 Cells}

Figure 9 illustrates the dose-dependent inhibition of cancer cell growth displayed by the CDDP formulations. At 3 to $20 \mu \mathrm{g} / \mathrm{mL}$ equivalent CDDP concentrations (NP concentrations from $\approx 20$ to $130 \mu \mathrm{g} / \mathrm{mL})$ ), it was observed a very significant enhancement of the antitumour activity of the chemotherapeutic when being loaded to the $\left(\gamma-\mathrm{Fe}_{2} \mathrm{O}_{3} / \mathrm{PLGA}\right) / \mathrm{CS}$ particles $(p<0.01)$. They were the nanoformulations that could be considered with cytotoxic potential, according to the ISO-10993-5 standard (RCV values < 70\%) [85]. Furthermore, the half maximal inhibitory concentration $\left(\mathrm{IC}_{50}\right)$ of the CDDP-loaded (core/shell)/shell NPs $(4.57 \pm 0.33 \mu \mathrm{g} / \mathrm{mL})$ was $\approx 1.6$-fold less than that of this platinum-based anticancer $\operatorname{drug}(7.48 \pm 0.37 \mu \mathrm{g} / \mathrm{mL})(p<0.05)$. This greater in-vitro cytotoxic activity agrees with preceding research in which CDDP loading to nanoparticulate systems is postulated to enable cellular uptake in malignant tissues [142,143]. 


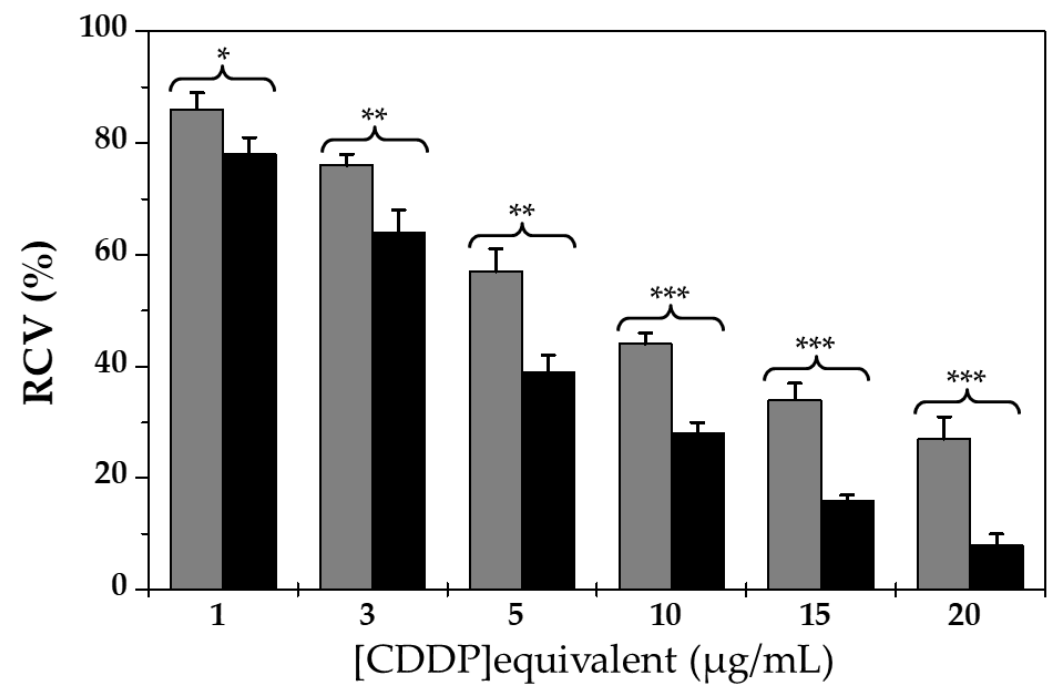

Figure 9. In-vitro cytotoxicity (RCV, \%) of CDDP-loaded ( $\left.\gamma-\mathrm{Fe}_{2} \mathrm{O}_{3} / \mathrm{PLGA}\right) / \mathrm{CS}$ NPs (black column) and free CDDP (light grey column) in human lung adenocarcinoma A-549 cells, after $72 \mathrm{~h}$ of exposure to a wide range of NP concentrations (up to $20 \mu \mathrm{g} / \mathrm{mL}$ equivalent CDDP concentration). The statistical Student's t-test, considering 95\% confidence interval, was significant $\left({ }^{*} p<0.05\right)$ or very significant $\left(* * p<0.01,{ }^{* * *} p<0.001\right)$, compared with the free CDDP-treated group.

Complementary in-vitro tests will help in providing clear evidence of the successful delivery of CDDP to tumour cells, and the real possibilities of these (core/shell)/shell NPs against lung cancer. For instance, the apoptosis assay involving annexin $\mathrm{V} /$ propidium iodide staining, the crystal violet staining experiment determining viability of cultured cells, and colony forming and cell migration assays to characterize the proliferative competence of the cancer cells on exposure to the CDDP-loaded NPs. Experiments in tumour-bearing mice will be also needed to clearly define the anticancer effect of the CDDP-loaded nanocomposites.

\section{Conclusions}

A reproducible procedure has been developed to prepare $\left(\gamma-\mathrm{Fe}_{2} \mathrm{O}_{3} /\right.$ PLGA $) /$ CS (core/shell)/shell NPs loaded with the chemotherapeutic CDDP $(\approx 330 \mathrm{~nm}$ in size, $\mathrm{PP} \approx 50 \%, \mathrm{DL} \approx 15 \%$ ). That nanostructure was reasonably characterized by EM, EDX, FTIR, and electrophoretic analyses. Short-term stability of the magnetic colloid was defined at room temperature. The high crystallinity and mineralogical purity of the iron oxide nuclei in the polymer matrices was proved by $\mathrm{X}$-ray diffraction analysis, being that these properties are possibly underneath the appropriate magnetism of the $\left(\gamma-\mathrm{Fe}_{2} \mathrm{O}_{3} / \mathrm{PLGA}\right) / \mathrm{CS}$ particles (demonstrated in vitro). Data from the cytotoxicity assays and ex-vivo hemocompatibility tests may suggest the in-vivo compatibility and safety of the (core/shell)/shell NPs, being that they are suitable for parenteral administration (and drug delivery). Furthermore, CDDP incorporation to this nanostructure generated a dual $\mathrm{pH}$ - and heat (hyperthermia)-responsive drug release behaviour $(\approx 4.7$-fold faster CDDP release at $\mathrm{pH} 5.0$ and $45^{\circ} \mathrm{C}$ compared to $\mathrm{pH} 7.4$ and $\left.37^{\circ} \mathrm{C}\right)$. To end, the CDDP-loaded $\left(\gamma-\mathrm{Fe}_{2} \mathrm{O}_{3} / \mathrm{PLGA}\right) / \mathrm{CS}$ particles demonstrated a better cytotoxicity than the free CDDP molecules against human lung adenocarcinoma A-549 cells ( $\mathrm{IC}_{50} \approx 1.6$-fold less than that of the chemotherapeutic) in absence of an applied magnetic field. Altogether, these biocompatible and tri-stimuli responsive $\left(\gamma-\mathrm{Fe}_{2} \mathrm{O}_{3} /\right.$ PLGA)/CS particles may become a contender in the lung cancer arena. Additional in-vitro and in-vivo experiments will contribute to the perfect definition of the therapeutic effectiveness of this nanostructure in cancer chemotherapy.

Author Contributions: Conceived and designed the experiments, F.F.-Á., J.L.A. Performed the experiments: F.F.-Á., G.G.-G. Analysed the data: F.F.-Á., G.G.-G., J.L.A. Contributed reagents/materials/analysis tools: J.L.A. Wrote the paper: F.F.-Á., J.L.A. All authors have read and agreed to the published version of the manuscript. 
Funding: This research was funded by Instituto de Salud Carlos III (ISCIII) (project PI19/01478) (FEDER), Programa Operativo FEDER de Andalucía 2014-2020 (Junta de Andalucía, project I + D + i A1-FQM-341-UGR18), and Programa de Ayudas a Proyectos I + D + i destinadas a Universidades y Entidades Públicas de Investigación (Junta de Andalucía, project PY20_00346).

Institutional Review Board Statement: Not applicable.

Informed Consent Statement: Not applicable.

Data Availability Statement: The experimental data have been provided within the manuscript.

Conflicts of Interest: The authors declare that they have no competing interests. The funders had no role in the design of the study; in the collection, analyses, or interpretation of data; in the writing of the manuscript, or in the decision to publish the results.

\section{References}

1. Alshehri, S.; Imam, S.S.; Rizwanullah, M.; Akhter, S.; Mahdi, W.; Kazi, M.; Ahmad, J. Progress of cancer nanotechnology as diagnostics, therapeutics, and theranostics nanomedicine: Preclinical promise and translational challenges. Pharmaceutics 2020, 13, 24. [CrossRef]

2. Kim, K.; Khang, D. Past, present, and future of anticancer nanomedicine. Int. J. Nanomed. 2020, 15, 5719-5743. [CrossRef] [PubMed]

3. Liu, S.; Khan, A.R.; Yang, X.; Dong, B.; Ji, J.; Zhai, G. The reversal of chemotherapy-induced multidrug resistance by nanomedicine for cancer therapy. J. Control. Release 2021, 335, 1-20. [CrossRef]

4. Zhang, Y.; He, Z.; Li, Y.; Xia, Q.; Li, Z.; Hou, X.; Feng, N. Tumor cell membrane-derived nano-Trojan horses encapsulating phototherapy and chemotherapy are accepted by homologous tumor cells. Mater. Sci. Eng. C 2021, 120, 111670. [CrossRef] [PubMed]

5. Pei, W.; Huang, B.; Chen, S.; Wang, L.; Xu, Y.; Niu, C. Platelet-mimicking drug delivery nanoparticles for enhanced chemophotothermal therapy of breast cancer. Int. J. Nanomed. 2020, 15, 10151-10167. [CrossRef]

6. Yang, S.-J.; Huang, C.-H.; Wang, C.-H.; Shieh, M.-J.; Chen, K.-C. The synergistic effect of hyperthermia and chemotherapy in magnetite nanomedicine-based lung cancer treatment. Int. J. Nanomed. 2020, 15, 10331-10347. [CrossRef]

7. Rahim, M.A.; Jan, N.; Khan, S.; Shah, H.; Madni, A.; Khan, A.; Jabar, A.; Khan, S.; Elhissi, A.; Hussain, Z.; et al. Recent advancements in stimuli responsive drug delivery platforms for active and passive cancer targeting. Cancers 2021, 13, 670. [CrossRef]

8. Boushehri, M.A.S.; Dietrich, D.; Lamprecht, A. Nanotechnology as a platform for the development of injectable parenteral formulations: A comprehensive review of the know-hows and state of the art. Pharmaceutics 2020, 12, 510. [CrossRef] [PubMed]

9. Fam, S.Y.; Chee, C.F.; Yong, C.Y.; Ho, K.L.; Mariatulqabtiah, A.R.; Tan, W.S. Stealth coating of nanoparticles in drug-delivery systems. Nanomaterials 2020, 10, 787. [CrossRef]

10. Woythe, L.; Tito, N.B.; Albertazzi, L. A quantitative view on multivalent nanomedicine targeting. Adv. Drug Deliv. Rev. 2021, 169, 1-21. [CrossRef] [PubMed]

11. Das, S.S.; Bharadwaj, P.; Bilal, M.; Barani, M.; Rahdar, A.; Taboada, P.; Bungau, S.; Kyzas, G.Z. Stimuli-responsive polymeric nanocarriers for drug delivery, imaging, and theragnosis. Polymers 2020, 12, 1397. [CrossRef]

12. Zhang, N.; Wang, D.; Yang, T.; Jing, X.; Meng, L. Construction of hyperbranched and pH-responsive polymeric nanocarriers by yne-phenol click-reaction for tumor synergistic chemotherapy. Colloids Surf. B Biointerfaces 2021, 204, 111790. [CrossRef]

13. Li, J.; Wang, Y.; Xu, C.; Yu, Q.; Wang, X.; Xie, H.; Tian, L.; Qiu, Y.; Guo, R.; Lu, Z.; et al. Rapid pH-responsive self-disintegrating nanoassemblies balance tumor accumulation and penetration for enhanced anti-breast cancer therapy. Acta Boimater. 2021. [CrossRef]

14. Afzalipour, R.; Khoei, S.; Khoee, S.; Shirvalilou, S.; Raoufi, N.J.; Motevalian, M.; Karimi, M.Y. Thermosensitive magnetic nanoparticles exposed to alternating magnetic field and heat-mediated chemotherapy for an effective dual therapy in rat glioma model. Nanomed. Nanotechnol. Boil. Med. 2021, 31, 102319. [CrossRef] [PubMed]

15. He, H.; Liu, L.; Zhang, S.; Zheng, M.; Ma, A.; Chen, Z.; Pan, H.; Zhou, H.; Liang, R.; Cai, L. Smart gold nanocages for mild heat-triggered drug release and breaking chemoresistance. J. Control. Release 2020, 323, 387-397. [CrossRef]

16. Xu, X.; Duan, J.; Liu, Y.; Kuang, Y.; Duan, J.; Liao, T.; Xu, Z.; Jiang, B.; Li, C. Multi-stimuli responsive hollow MnO2-based drug delivery system for magnetic resonance imaging and combined chemo-chemodynamic cancer therapy. Acta Biomater. 2021, 126, 445-462. [CrossRef]

17. Xu, J.; Yan, X.; Ge, X.; Zhang, M.; Dang, X.; Yang, Y.; Xu, F.; Luo, Y.; Li, G. Novel multi-stimuli responsive functionalized PEG-based co-delivery nanovehicles toward sustainable treatments of multidrug resistant tumor. J. Mater. Chem. B 2021, 9 , 1297-1314. [CrossRef]

18. El-Hammadi, M.M.; Arias, J.L. Iron oxide-based multifunctional nanoparticulate systems for biomedical applications: A patent review (2008-present). Expert Opin. Ther. Pat. 2015, 25, 691-709. [CrossRef] [PubMed] 
19. Dhas, N.; Kudarha, R.; Pandey, A.; Nikam, A.N.; Sharma, S.; Singh, A.; Garkal, A.; Hariharan, K.; Singh, A.; Bangar, P.; et al. Stimuli responsive and receptor targeted iron oxide based nanoplatforms for multimodal therapy and imaging of cancer: Conjugation chemistry and alternative therapeutic strategies. J. Control. Release 2021, 333, 188-245. [CrossRef]

20. Mansur, A.A.P.; Mansur, H.S.; Leonel, A.G.; Carvalho, I.C.; Lage, M.C.G.; Carvalho, S.M.; Krambrock, K.; Lobato, Z.I.P. Supramolecular magnetonanohybrids for multimodal targeted therapy of triple-negative breast cancer cells. J. Mater. Chem. $B$ 2020, 8, 7166-7188. [CrossRef] [PubMed]

21. Taheri-Ledari, R.; Zhang, W.; Radmanesh, M.; Mirmohammadi, S.S.; Maleki, A.; Cathcart, N.; Kitaev, V. Multi-stimuli nanocomposite therapeutic: Docetaxel targeted delivery and synergies in treatment of human breast cancer tumor. Small 2020, 16, e2002733. [CrossRef]

22. Reddy, L.H.; Arias, J.L.; Nicolas, J.; Couvreur, P. Magnetic nanoparticles: Design and characterization, toxicity and biocompatibility, pharmaceutical and biomedical applications. Chem. Rev. 2012, 112, 5818-5878. [CrossRef]

23. Lorente, C.; Cabeza, L.; Clares, B.; Ortiz, R.; Halbaut, L.; Delgado, Á.V.; Perazzoli, G.; Prados, J.; Arias, J.L.; Melguizo, C. Formulation and in vitro evaluation of magnetoliposomes as a potential nanotool in colorectal cancer therapy. Colloids Surf. B Biointerfaces 2018, 171, 553-565. [CrossRef] [PubMed]

24. Curcio, A.; Silva, A.K.A.; Cabana, S.; Espinosa, A.; Baptiste, B.; Menguy, N.; Wilhelm, C.; Abou-Hassan, A. Iron oxide nanoflowers @ CuS hybrids for cancer tri-therapy: Interplay of photothermal therapy, magnetic hyperthermia and photodynamic therapy. Theranostics 2019, 9, 1288-1302. [CrossRef]

25. Benyettou, F.; Das, G.; Nair, A.R.; Prakasam, T.; Shinde, D.B.; Sharma, S.K.; Whelan, J.; Lalatonne, Y.; Traboulsi, H.; Pasricha, R.; et al. Covalent organic framework embedded with magnetic nanoparticles for MRI and chemo-thermotherapy. J. Am. Chem. Soc. 2020, 142, 18782-18794. [CrossRef] [PubMed]

26. Mosiniewicz-Szablewska, E.; Tedesco, A.C.; Suchocki, P.; Morais, P.C. Magnetic studies of polylactic-co-glicolic acid nanocapsules loaded with selol and $\gamma$-Fe2O3 nanoparticles. Phys. Chem. Chem. Phys. 2020, 22, 21042-21058. [CrossRef]

27. Moskvin, M.; Huntošová, V.; Herynek, V.; Matouš, P.; Michalcová, A.; Lobaz, V.; Zasońska, B.; Šlouf, M.; Seliga, R.; Horák, D. In vitro cellular activity of maghemite/cerium oxide magnetic nanoparticles with antioxidant properties. Colloids Surf B Biointerfaces 2021, 204, 111824. [CrossRef]

28. Sneha, K.R.; Sreeja, S.; Sailaja, G.S. Radiopacity endowed magnetic nanocomposite with hyperthermia andin vitromineralization potential: A combinatorial therapeutic system for osteosarcoma. Biomed. Mater. 2021, 16, 045029. [CrossRef]

29. Xie, Q.; Wen, T.; Yang, A.; Zhang, X.; Chen, B.; Meng, J.; Liu, J.; Gu, N.; Xu, H. A contrast examination of proinflammatory effects on kidney function for $\gamma$-Fe2O3 NP and gadolinium dimeglumine. Int. J. Nanomed. 2021, 16, 2271-2282. [CrossRef]

30. Lee, S.-J.; Kim, H.-J.; Huh, Y.-M.; Kim, I.W.; Jeong, J.H.; Kim, J.-C.; Kim, J.-D. Functionalized magnetic PLGA nanospheres for targeting and bioimaging of breast cancer. J. Nanosci. Nanotechnol. 2018, 18, 1542-1547. [CrossRef]

31. Morovati, A.; Ahmadian, S.; Jafary, H. Cytotoxic effects and apoptosis induction of cisplatin-loaded iron oxide nanoparticles modified with chitosan in human breast cancer cells. Mol. Biol. Rep. 2019, 46, 5033-5039. [CrossRef]

32. García-García, G.; Fernández-Álvarez, F.; Cabeza, L.; Delgado, Á.V.; Melguizo, C.; Prados, J.C.; Arias, J.L. Gemcitabine-loaded magnetically responsive poly( $\varepsilon$-caprolactone) nanoparticles against breast cancer. Polymers 2020, 12, 2790. [CrossRef] [PubMed]

33. Cui, Y.-N.; Xu, Q.-X.; Davoodi, P.; Wang, D.-P.; Wang, C.-H. Enhanced intracellular delivery and controlled drug release of magnetic PLGA nanoparticles modified with transferrin. Acta Pharmacol. Sin. 2017, 38, 943-953. [CrossRef]

34. Mosafer, J.; Teymouri, M.; Abnous, K.; Tafaghodi, M.; Ramezani, M. Study and evaluation of nucleolin-targeted delivery of magnetic PLGA-PEG nanospheres loaded with doxorubicin to C6 glioma cells compared with low nucleolin-expressing L929 cells. Mater. Sci. Eng. C 2017, 72, 123-133. [CrossRef]

35. Park, J.; Park, J.; Castanares, M.A.; Collins, D.S.; Yeo, Y. Magnetophoretic delivery of a tumor-priming agent for chemotherapy of metastatic murine breast cancer. Mol. Pharm. 2019, 16, 1864-1873. [CrossRef] [PubMed]

36. Jain, G.K.; Pathan, S.A.; Akhter, S.; Ahmad, N.; Jain, N.; Talegaonkar, S.; Khar, R.K.; Ahmad, F.J. Mechanistic study of hydrolytic erosion and drug release behaviour of PLGA nanoparticles: Influence of chitosan. Polym. Degrad. Stab. 2010, 95, 2360-2366. [CrossRef]

37. Domínguez-Ríos, R.; Sánchez-Ramírez, D.R.; Ruiz-Saray, K.; Oceguera-Basurto, P.E.; Almada, M.; Juárez, J.; Zepeda-Moreno, A.; Del Toro-Arreola, A.; Topete, A.; Daneri-Navarro, A. Cisplatin-loaded PLGA nanoparticles for HER2 targeted ovarian cancer therapy. Colloids Surf. B Biointerfaces 2019, 178, 199-207. [CrossRef] [PubMed]

38. Lappe, S.; Mulac, D.; Langer, K. Polymeric nanoparticles-Influence of the glass transition temperature on drug release. Int. J. Pharm. 2017, 517, 338-347. [CrossRef]

39. Park, K.; Otte, A.; Sharifi, F.; Garner, J.; Skidmore, S.; Park, H.; Jhon, Y.K.; Qin, B.; Wang, Y. Potential roles of the glass transition temperature of PLGA microparticles in drug release kinetics. Mol. Pharm. 2021, 18, 18-32. [CrossRef]

40. Dunne, M.; Corrigan, O.I.; Ramtoola, Z. Influence of particle size and dissolution conditions on the degradation properties of polylactide-co-glycolide particles. Biomaterials 2000, 21, 1659-1668. [CrossRef]

41. Souza, K.C.; Ardisson, J.D.; Sousa, E.M.B. Study of mesoporous silica/magnetite systems in drug controlled release. J. Mater. Sci. Mater. Med. 2009, 20, 507-512. [CrossRef] [PubMed]

42. Arias, J.L.; Reddy, L.H.; Couvreur, P.; Patrick, C. Superior preclinical efficacy of gemcitabine developed as chitosan nanoparticulate system. Biomacromolecules 2011, 12, 97-104. [CrossRef] 
43. Taghavi, S.; Ramezani, M.; Alibolandi, M.; Abnous, K.; Taghdisi, S.M. Chitosan-modified PLGA nanoparticles tagged with 5TR1 aptamer for in vivo tumor-targeted drug delivery. Cancer Lett. 2017, 400, 1-8. [CrossRef] [PubMed]

44. Ishak, R.A.; Awad, G.A.; Zaki, N.M.; El-Shamy, A.E.H.A.; Mortada, N.D. A comparative study of chitosan shielding effect on nano-carriers hydrophilicity and biodistribution. Carbohydr. Polym. 2013, 94, 669-676. [CrossRef]

45. Chirio, D.; Peira, E.; Sapino, S.; Dianzani, C.; Barge, A.; Muntoni, E.; Morel, S.; Gallarate, M. Stearoyl-chitosan coated nanoparticles obtained by microemulsion cold dilution technique. Int. J. Mol. Sci. 2018, 19, 3833. [CrossRef]

46. Pustulka, S.M.; Ling, K.; Pish, S.L.; Champion, J.A. Protein nanoparticle charge and hydrophobicity govern protein corona and macrophage uptake. ACS Appl. Mater. Interfaces 2020, 12, 48284-48295. [CrossRef]

47. Aggarwal, P.; Hall, J.B.; McLeland, C.B.; Dobrovolskaia, M.A.; McNeil, S.E. Nanoparticle interaction with plasma proteins as it relates to particle biodistribution, biocompatibility and therapeutic efficacy. Adv. Drug Deliv. Rev. 2009, 61, 428-437. [CrossRef] [PubMed]

48. Yue, Z.-G.; Wei, W.; Lv, P.-P.; Yue, H.; Wang, L.-Y.; Su, Z.-G.; Ma, G.-H. Surface charge affects cellular uptake and intracellular trafficking of chitosan-based nanoparticles. Biomacromolecules 2011, 12, 2440-2446. [CrossRef] [PubMed]

49. Babu, A.; Amreddy, N.; Muralidharan, R.; Pathuri, G.; Gali, H.; Chen, A.; Zhao, Y.D.; Munshi, A.; Ramesh, R. Chemodrug delivery using integrin-targeted PLGA-Chitosan nanoparticle for lung cancer therapy. Sci. Rep. 2017, 7, 14674. [CrossRef] [PubMed]

50. Durán-Lobato, M.; Muñoz-Rubio, I.; Holgado, M.A.; Alvarez-Fuentes, J.; Fernández-Arévalo, M.; Martín-Banderas, L. Enhanced cellular uptake and biodistribution of a synthetic cannabinoid loaded in surface-modified poly(lactic-co-glycolic acid) nanoparticles. J. Biomed. Nanotechnol. 2014, 10, 1068-1079. [CrossRef] [PubMed]

51. Mansouri, A.; Abnous, K.; Alibolandi, M.; Taghdisi, S.M.; Ramezani, M. Targeted delivery of tacrolimus to T cells by pHresponsive aptamer-chitosan- poly(lactic-co-glycolic acid) nanocomplex. J. Cell. Physiol. 2019, 234, 18262-18271. [CrossRef]

52. Li, W.; Yalcin, M.; Lin, Q.; Ardawi, M.-S.M.; Mousa, S.A. Self-assembly of green tea catechin derivatives in nanoparticles for oral lycopene delivery. J. Control. Release 2017, 248, 117-124. [CrossRef] [PubMed]

53. Ibarra, J.; Melendres, J.; Almada, M.; Burboa, M.G.; Taboada, P.; Juárez, J.; Valdez, M.A. Synthesis and characterization of magnetite/PLGA/chitosan nanoparticles. Mater. Res. Express 2015, 2, 095010. [CrossRef]

54. Li, G.; Wang, Y.; Tan, G. The construction of EpCAM/vimentin-PLGA/lipid immunomagnetic microspheres and the isolation of circulating tumor cells from lung cancer. Int. J. Clin. Exp. Pathol. 2018, 11, 5561-5570.

55. Fernández-Álvarez, F.; Caro, C.; García-García, G.; García-Martín, M.L.; Arias, J.L. Engineering of stealth (maghemite/PLGA)/chitosan (core/shell)/shell nanocomposites with potential applications for combined MRI and hyperthermia against cancer. J. Mater. Chem. B 2021, 9, 4963-4980. [CrossRef] [PubMed]

56. Dasari, S.; Tchounwou, P.B. Cisplatin in cancer therapy: Molecular mechanisms of action. Eur. J. Pharmacol. 2014, 740, 364-378. [CrossRef]

57. van Hennik, M.B.; van der Vijgh, W.J.; Klein, I.; Elferink, F.; Vermorken, J.B.; Winograd, B.; Pinedo, H.M. Comparative pharmacokinetics of cisplatin and three analogues in mice and humans. Cancer Res. 1987, 47, 6297-6301.

58. Avgoustakis, K.; Beletsi, A.; Panagi, Z.; Klepetsanis, P.; Karydas, A.G.; Ithakissios, D.S. PLGA—mPEG nanoparticles of cisplatin: In vitro nanoparticle degradation, in vitro drug release and in vivo drug residence in blood properties. J. Control. Release 2002, 79, 123-135. [CrossRef]

59. Mattheolabakis, G.; Taoufik, E.; Haralambous, S.; Roberts, M.L.; Avgoustakis, K. In vivo investigation of tolerance and antitumor activity of cisplatin-loaded PLGA-mPEG nanoparticles. Eur. J. Pharm. Biopharm. 2009, 71, 190-195. [CrossRef]

60. Kim, J.-H.; Kim, Y.-S.; Park, K.; Lee, S.; Nam, H.Y.; Min, K.H.; Jo, H.G.; Park, J.H.; Choi, K.; Jeong, S.Y.; et al. Antitumor efficacy of cisplatin-loaded glycol chitosan nanoparticles in tumor-bearing mice. J. Control. Release 2008, 127, 41-49. [CrossRef]

61. Nejati-Koshki, K.; Mesgari, M.; Ebrahimi, E.; Abbasalizadeh, F.; Fekri-Aval, S.; Khandaghi, A.A.; Abasi, M.; Akbarzadeh, A. Synthesis and in vitro study of cisplatin-loaded Fe3O4 nanoparticles modified with PLGA-PEG6000 copolymers in treatment of lung cancer. J. Microencapsul. 2014, 31, 815-823. [CrossRef] [PubMed]

62. Babincova, M.; Altanerova, V.; Altaner, C.; Bergemann, C.; Babinec, P. In vitro analysis of cisplatin functionalized magnetic nanoparticles in combined cancer chemotherapy and electromagnetic hyperthermia. IEEE Trans. Nanobiosci. 2008, 7, 15-19. [CrossRef]

63. Pina, M.F.; Lau, W.; Scherer, K.; Parhizkar, M.; Edirisinghe, M.; Craig, D. The generation of compartmentalized nanoparticles containing siRNA and cisplatin using a multi-needle electrohydrodynamic strategy. Nanoscale 2017, 9, 5975-5985. [CrossRef]

64. Massart, R. Preparation of aqueous magnetic liquids in alkaline and acidic media. IEEE Trans. Magn. 1981, 17, 1247-1248. [CrossRef]

65. Bee, A.; Massart, R.; Neveu, S. Synthesis of very fine maghemite particles. J. Magn. Magn. Mater. 1995, 149, 6-9. [CrossRef]

66. Matshaya, T.J.; Lanterna, A.E.; Granados, A.M.; Krause, R.W.M.; Maggio, B.; Vico, R.V. Distinctive interactions of oleic acid covered magnetic nanoparticles with saturated and unsaturated phospholipids in Langmuir monolayers. Langmuir 2014, 30, 5888-5896. [CrossRef] [PubMed]

67. El-Hammadi, M.M.; Delgado, Á.V.; Melguizo, C.; Prados, J.C.; Arias, J.L. Folic acid-decorated and PEGylated PLGA nanoparticles for improving the antitumour activity of 5-fluorouracil. Int. J. Pharm. 2017, 516, 61-70. [CrossRef] [PubMed]

68. Unciti-Broceta, J.D.; Arias, J.L.; Maceira, J.; Soriano, M.; Ortiz-González, M.; Hernández-Quero, J.; Muñóz-Torres, M.; de Koning, H.P.; Magez, S.; Garcia-Salcedo, J.A. Specific cell targeting therapy bypasses drug resistance mechanisms in African Trypanosomiasis. PLoS Pathog. 2015, 11, e1004942. [CrossRef] [PubMed] 
69. Almalik, A.; Benabdelkamel, H.; Masood, A.; Alanazi, I.O.; Alradwan, I.; Majrashi, M.A.; Alfadda, A.A.; Alghamdi, W.M.; Alrabiah, H.; Tirelli, N.; et al. Hyaluronic acid coated chitosan nanoparticles reduced the immunogenicity of the formed protein corona. Sci. Rep. 2017, 7, 10542. [CrossRef]

70. Krauss, I.R.; Picariello, A.; Vitiello, G.; De Santis, A.; Koutsioubas, A.; Houston, J.E.; Fragneto, G.; Paduano, L. Interaction with human serum proteins reveals biocompatibility of phosphocholine-functionalized SPIONs and formation of albumin-decorated nanoparticles. Langmuir 2020, 36, 8777-8791. [CrossRef]

71. Plaza, R.C.; Arias, J.L.; Espín, M.J.; Jiménez, M.L.; Delgado, A.V. Aging effects in the electrokinetics of colloidal iron oxides. J. Colloid Interface Sci. 2002, 245, 86-90. [CrossRef]

72. Arias, J.L.; Gallardo, V.; Gómez-Lopera, S.A.; Plaza, R.C.; Delgado, A.V. Synthesis and characterization of poly(ethyl-2cyanoacrylate) nanoparticles with a magnetic core. J. Control. Release 2001, 77, 309-321. [CrossRef]

73. Arias, J.L.; Gallardo, V.; Linares-Molinero, F.; Delgado, A.V. Preparation and characterization of carbonyl iron/poly(butylcyanoacrylate) core/shell nanoparticles. J. Colloid Interface Sci. 2006, 299, 599-607. [CrossRef]

74. Andersen, H.L.; Saura-Múzquiz, M.; Granados-Miralles, C.; Canévet, E.; Lock, N.; Christensen, M. Crystalline and magnetic structure-property relationship in spinel ferrite nanoparticles. Nanoscale 2018, 10, 14902-14914. [CrossRef] [PubMed]

75. Thévenot, J.; Oliveira, H.; Sandre, O.; Lecommandoux, S. Magnetic responsive polymer composite materials. Chem. Soc. Rev. 2013, 42, 7099-7116. [CrossRef] [PubMed]

76. Fang, K.; Song, L.; Gu, Z.; Yang, F.; Zhang, Y.; Gu, N. Magnetic field activated drug release system based on magnetic PLGA microspheres for chemo-thermal therapy. Colloids Surf. B Biointerfaces 2015, 136, 712-720. [CrossRef]

77. Silva, E.D.; Babo, P.S.; Costa-Almeida, R.; Domingues, R.M.A.; Mendes, B.B.; Paz, E.; Freitas, P.; Rodrigues, M.T.; Granja, P.L.; Gomes, M.E. Multifunctional magnetic-responsive hydrogels to engineer tendon-to-bone interface. Nanomed. Nanotechnol. Biol. Med. 2018, 14, 2375-2385. [CrossRef]

78. Dash, B.C.; Réthoré, G.; Monaghan, M.; Fitzgerald, K.; Gallagher, W.; Pandit, A. The influence of size and charge of chitosan/polyglutamic acid hollow spheres on cellular internalization, viability and blood compatibility. Biomaterials 2010, 31, 8188-8197. [CrossRef]

79. de Escalona, M.M.; Sáez-Fernández, E.; Prados, J.C.; Melguizo, C.; Arias, J.L. Magnetic solid lipid nanoparticles in hyperthermia against colon cancer. Int. J. Pharm. 2016, 504, 11-19. [CrossRef] [PubMed]

80. Chen, D.; Lian, S.; Sun, J.; Liu, Z.; Zhao, F.; Jiang, Y.; Gao, M.; Sun, K.; Liu, W.; Fu, F. Design of novel multifunctional targeting nano-carrier drug delivery system based on CD44 receptor and tumor microenvironment $\mathrm{pH}$ condition. Drug Deliv. 2016, 23, 808-813. [CrossRef]

81. Kim, H.-C.; Kim, E.; Jeong, S.W.; Ha, T.-L.; Park, S.-I.; Lee, S.G.; Lee, S.J.; Lee, S.W. Magnetic nanoparticle-conjugated polymeric micelles for combined hyperthermia and chemotherapy. Nanoscale 2015, 7, 16470-16480. [CrossRef]

82. Chen, L.; Zhang, H.; Zheng, J.; Yu, S.; Du, J.; Yang, Y.; Liu, X. Thermo-sensitively and magnetically ordered mesoporous carbon nanospheres for targeted controlled drug release and hyperthermia application. Mater. Sci. Eng. C 2018, 84, 21-31. [CrossRef]

83. Amin, M.; Huang, W.; Seynhaeve, A.L.B.; Hagen, T.L.M.T. Hyperthermia and temperature-sensitive nanomaterials for spatiotemporal drug delivery to solid tumors. Pharmaceutics 2020, 12, 1007. [CrossRef] [PubMed]

84. Park, J.; Jin, C.; Lee, S.; Kim, J.Y.; Choi, H. Magnetically actuated degradable microrobots for actively controlled drug release and hyperthermia therapy. Adv. Healthc. Mater. 2019, 8, e1900213. [CrossRef] [PubMed]

85. International Organization for Standardization. Biological Evaluation of Medical Devices—Part 5: Tests for in Vitro Cytotoxicity (ISO 10993-5:2009). 2009. Available online: https://www.iso.org/standard/36406.html (accessed on 16 March 2021).

86. Saddik, M.S.; Elsayed, M.M.A.; Abdelkader, M.S.A.; El-Mokhtar, M.A.; Abdel-Aleem, J.A.; Abu-Dief, A.M.; Al-Hakkani, M.F.; Farghaly, H.S.; Abou-Taleb, H.A. Novel green biosynthesis of 5-fluorouracil chromium nanoparticles using Harpullia pendula extract for treatment of colorectal cancer. Pharmaceutics 2021, 13, 226. [CrossRef] [PubMed]

87. Wang, X.; Cheng, R.; Zhong, Z. Facile fabrication of robust, hyaluronic acid-surfaced and disulfide-crosslinked PLGA nanoparticles for tumor-targeted and reduction-triggered release of docetaxel. Acta Biomater. 2021, 125, 280-289. [CrossRef]

88. Gaumet, M.; Vargas, A.; Gurny, R.; Delie, F. Nanoparticles for drug delivery: The need for precision in reporting particle size parameters. Eur. J. Pharm. Biopharm. 2008, 69, 1-9. [CrossRef]

89. Schädlich, A.; Caysa, H.; Mueller, T.; Tenambergen, F.; Rose, C.; Göpferich, A.; Kuntsche, J.; Mäder, K. Tumor accumulation of NIR fluorescent PEG-PLA nanoparticles: Impact of particle size and human xenograft tumor model. ACS Nano 2011, 5, 8710-8720. [CrossRef] [PubMed]

90. Yuan, F.; Dellian, M.; Fukumura, D.; Leunig, M.; Berk, D.A.; Torchilin, V.P.; Jain, R.K. Vascular permeability in a human tumor xenograft: Molecular size dependence and cutoff size. Cancer Res. 1995, 55, 3752-3756. [PubMed]

91. Wang, J.; Sui, M.; Fan, W. Nanoparticles for tumor targeted therapies and their pharmacokinetics. Curr. Drug Metab. 2010, 11, 129-141. [CrossRef]

92. Moreno, D.; Zalba, S.; Navarro, I.; de Ilarduya, C.T.; Garrido, M.J. Pharmacodynamics of cisplatin-loaded PLGA nanoparticles administered to tumor-bearing mice. Eur. J. Pharm. Biopharm. 2010, 74, 265-274. [CrossRef]

93. Abouelmagd, S.A.; Ku, Y.J.; Yeo, Y. Low molecular weight chitosan-coated polymeric nanoparticles for sustained and $\mathrm{pH}$-sensitive delivery of paclitaxel. J. Drug Target. 2015, 23, 725-735. [CrossRef] 
94. Voon, S.H.; Tiew, S.X.; Kue, C.S.; Lee, H.B.; Kiew, L.V.; Misran, M.; Kamkaew, A.; Burgess, K.; Chung, L.Y. Chitosan-coated poly(lactic-co-glycolic acid)-diiodinated boron-dipyrromethene nanoparticles improve tumor selectivity and stealth properties in photodynamic cancer therapy. J. Biomed. Nanotechnol. 2016, 12, 1431-1452. [CrossRef]

95. Sanna, V.; Roggio, A.M.; Siliani, S.; Piccinini, M.; Marceddu, S.; Mariani, A.; Sechi, M. Development of novel cationic chitosan-and anionic alginate-coated poly(D,L-lactide-co-glycolide) nanoparticles for controlled release and light protection of resveratrol. Int. J. Nanomed. 2012, 7, 5501-5516. [CrossRef]

96. Tong, G.-F.; Qin, N.; Sun, L.-W. Development and evaluation of Desvenlafaxine loaded PLGA-chitosan nanoparticles for brain delivery. Saudi Pharm. J. 2017, 25, 844-851. [CrossRef]

97. Gao, P.; Mei, C.; He, L.; Xiao, Z.; Chan, L.; Zhang, D.; Shi, C.; Chen, T.; Luo, L. Designing multifunctional cancer-targeted nanosystem for magnetic resonance molecular imaging-guided theranostics of lung cancer. Drug Deliv. 2018, 25, 1811-1825. [CrossRef]

98. Avadi, M.R.; Sadeghi, A.M.M.; Mohammadpour, N.; Abedin, S.; Atyabi, F.; Dinarvand, R.; Rafiee-Tehrani, M. Preparation and characterization of insulin nanoparticles using chitosan and Arabic gum with ionic gelation method. Nanomedicine 2010, 6, 58-63. [CrossRef] [PubMed]

99. Tzeyung, A.S.; Md, S.; Bhattamisra, S.K.; Madheswaran, T.; Alhakamy, N.A.; Aldawsari, H.M.; Radhakrishnan, A.K. Fabrication, Optimization, and Evaluation of Rotigotine-Loaded Chitosan Nanoparticles for Nose-To-Brain Delivery. Pharmaceutics 2019, 11, 26. [CrossRef]

100. Santos, D.P.; Ruiz, M.A.; Gallardo, V.; Zanoni, M.V.B.; Arias, J.L. Multifunctional antitumor magnetite/chitosan-L-glutamic acid (core/shell) nanocomposites. J. Nanoparicle Res. 2011, 13, 4311-4323. [CrossRef]

101. Arias, J.L.; Reddy, L.H.; Couvreur, P. Fe3O4/chitosan nanocomposite for magnetic drug targeting to cancer. J. Mater. Chem. 2012, 22, 7622-7632. [CrossRef]

102. Nasrazadani, S.; Hassani, S. Modern analytical techniques in failure analysis of aerospace, chemical, and oil and gas industries. In Handbook of Materials Failure Analysis with Case Studies from the Oil and Gas Industry; Makhlouf, A.S.H., Aliofkhazraei, M., Eds.; Butterworth-Heinemann: Oxford, UK, 2016; pp. 39-54. [CrossRef]

103. Holgado, M.A.; Alvarez-Fuentes, J.; Fernández-Arévalo, M.; Arias, J.L. Possibilities of poly(D,L-lactide-co-glycolide) in the formulation of nanomedicines against cancer. Curr. Drug Targets 2011, 12, 1096-1111. [CrossRef] [PubMed]

104. Pérez-Artacho, B.; Gallardo, V.; Ruiz, M.A.; Arias, J.L. Maghemite/poly(D,L-lactide-co-glycolyde) composite nanoplatform for therapeutic applications. J. Nanoparticle Res. 2012, 14, 1-10. [CrossRef]

105. Arias, J.L.; López-Viota, M.; Gallardo, V.; Ruiz, M.A. Chitosan nanoparticles as a new delivery system for the chemotherapy agent tegafur. Drug Dev. Ind. Pharm. 2010, 36, 744-750. [CrossRef]

106. Lyklema, J. The role of surface conduction in the development of electrokinetics. In Interfacial Electrokinetics and Electrophoresis; Delgado, A.V., Ed.; Marcel Dekker: New York, NY, USA, 2002; pp. 87-97.

107. Arias, J.L.; Martínez-Soler, G.I.; López-Viota, M.; Ruiz, M.A. Formulation of chitosan nanoparticles loaded with metronidazole for the treatment of infectious diseases. Lett. Drug Des. Discov. 2010, 7, 70-78. [CrossRef]

108. Chronopoulou, L.; Massimi, M.; Giardi, M.F.; Cametti, C.; Devirgiliis, L.C.; Dentini, M.; Palocci, C. Chitosan-coated PLGA nanoparticles: A sustained drug release strategy for cell cultures. Colloids Surf. B Biointerfaces 2013, 103, 310-317. [CrossRef] [PubMed]

109. Xie, D.; Huang, H.; Blackwood, K.; MacNeil, S. A novel route for the production of chitosan/poly(lactide-co-glycolide) graft copolymers for electrospinning. Biomed. Mater. 2010, 5, 065016. [CrossRef]

110. Wang, Y.; Li, P.; Kong, L. Chitosan-modified PLGA nanoparticles with versatile surface for improved drug delivery. AAPS PharmSciTech. 2013, 14, 585-592. [CrossRef]

111. Martín-Banderas, L.; Muñoz-Rubio, I.; Álvarez-Fuentes, J.; Durán-Lobato, M.; Arias, J.L.; Holgado, M.Á.; Fernández-Arévalo, M. Engineering of $\Delta$ 9-tetrahydrocannabinol delivery systems based on surface modified-PLGA nanoplatforms. Colloids Surf. B Biointerfaces 2014, 123, 114-122. [CrossRef]

112. Badran, M.M.; Alomrani, A.H.; Harisa, G.I.; Ashour, A.E.; Kumar, A.; Yassin, A.E. Novel docetaxel chitosan-coated PLGA/PCL nanoparticles with magnified cytotoxicity and bioavailability. Biomed. Pharmacother. 2018, 106, 1461-1468. [CrossRef]

113. Amin, M.K.; Boateng, J.S. Comparison and process optimization of PLGA, chitosan and silica nanoparticles for potential oral vaccine delivery. Ther. Deliv. 2019, 10, 493-514. [CrossRef] [PubMed]

114. Haider, M.; Elsherbeny, A.; Jagal, J.; Hubatová-Vacková, A.; Ahmed, I.S. Optimization and evaluation of poly(lactide-co-glycolide) nanoparticles for enhanced cellular uptake and efficacy of paclitaxel in the treatment of head and neck cancer. Pharmaceutics 2020, 12, 828. [CrossRef] [PubMed]

115. Montha, W.; Maneeprakorn, W.; Buatong, N.; Tang, I.-M.; Pon-On, W. Synthesis of doxorubicin-PLGA loaded chitosan stabilized (Mn, $\mathrm{Zn}) \mathrm{Fe}_{2} \mathrm{O}_{4}$ nanoparticles: Biological activity and $\mathrm{pH}$-responsive drug release. Mater. Sci. Eng. C 2016, 59, 235-240. [CrossRef] [PubMed]

116. Thakur, C.K.; Thotakura, N.; Kumar, R.; Kumar, P.; Singh, B.; Chitkara, D.; Raza, K. Chitosan-modified PLGA polymeric nanocarriers with better delivery potential for tamoxifen. Int. J. Biol. Macromol. 2016, 93, 381-389. [CrossRef] [PubMed]

117. Silverstein, R.M.; Webster, F.X. Spectrometric Identification of Organic Compounds, 6th ed.; John Wiley \& Sons: New York, NY, USA, 1998.

118. Lyon, R.J.P. Infrared absorption spectroscopy. In Physical Methods, in determinative Mineralogy; Zussman, J., Ed.; Academic Press: London, UK, 1967; pp. 371-399. 
119. Idris, M.I.; Zaloga, J.; Detsch, R.; Roether, J.A.; Unterweger, H.; Alexiou, C.; Boccaccini, A.R. Surface modification of SPIONs in PHBV microspheres for biomedical applications. Sci. Rep. 2018, 8, 7286. [CrossRef] [PubMed]

120. Depeyrot, J.; Sousa, E.C.; Aquino, R.; Tourinho, F.A.; Dubois, E.; Bacri, J.-C.; Perzynski, R. Rare earth doped maghemite EDL-MF: A perspective for nanoradiotherapy? J. Magn. Magn. Mater. 2002, 252, 375-377. [CrossRef]

121. Ling, Y.; Long, M.; Hu, P.; Chen, Y.; Huang, J. Magnetically separable core-shell structural $\gamma$-Fe2O3@Cu/Al-MCM-41 nanocomposite and its performance in heterogeneous Fenton catalysis. J. Hazard. Mater. 2014, 264, 195-202. [CrossRef]

122. Narimani-Sabegh, S.; Noroozian, E. Magnetic solid-phase extraction and determination of ultra-trace amounts of antimony in aqueous solutions using maghemite nanoparticles. Food Chem. 2019, 287, 382-389. [CrossRef] [PubMed]

123. Raut, A.V.; Yadav, H.M.; Gnanamani, A.; Pushpavanam, S.; Pawar, S.H. Synthesis and characterization of chitosan-TiO2:Cu nanocomposite and their enhanced antimicrobial activity with visible light. Colloids Surf. B Biointerfaces 2016, 148, 566-575. [CrossRef]

124. Soltani, S.; Ebrahimian-Hosseinabadi, M.; Kharazi, A.Z. Chitosan/graphene and poly(D, L-lactic-co-glycolic acid)/graphene nano-composites for nerve tissue engineering. Tissue Eng. Regen. Med. 2016, 13, 684-690. [CrossRef]

125. Zhang, Q.; Zhao, D.; Feng, S.; Wang, Y.; Jin, J.; Alsaedi, A.; Hayat, T.; Chen, C. Synthesis of nanoscale zero-valent iron loaded chitosan for synergistically enhanced removal of U(VI) based on adsorption and reduction. J. Colloid Interface Sci. 2019, 552, 735-743. [CrossRef]

126. Dillen, K.; Vandervoort, J.; Van den Mooter, G.; Verheyden, L.; Ludwig, A. Factorial design, physicochemical characterisation and activity of ciprofloxacin-PLGA nanoparticles. Int. J. Pharm. 2004, 275, 171-187. [CrossRef] [PubMed]

127. Lima, T.C.; Lucarini, R.; Luz, P.P.; de Faria, E.H.; Marçal, L.; Magalhães, L.G.; Badoco, F.R.; Esperandim, V.R.; Molina, E.F.; Laurentz, R.S.; et al. In vitro schistosomicidal activity of the lignan (-)-6,6'-dinitrohinokinin (DNHK) loaded into poly(lactic-co-glycolic acid) nanoparticles against Schistosoma mansoni. Pharm. Biol. 2017, 55, 2270-2276. [CrossRef]

128. Ray, S.; Ghosh, S.; Mandal, S. Development of bicalutamide-loaded PLGA nanoparticles: Preparation, characterization and in-vitro evaluation for the treatment of prostate cancer. Artif. Cells Nanomed. Biotechnol. 2017, 45, 944-954. [CrossRef]

129. Nguyen, T.H.A.; Nguyen, V.C. Formation of nanoparticles in aqueous solution from poly(e-caprolactone)-poly(ethylene glycol)poly(E-caprolactone). Adv. Nat. Sci. Nanosci. Nanotechnol. 2010, 1, 025012. [CrossRef]

130. Bae, S.H.; Che, J.H.; Seo, J.M.; Jeong, J.; Kim, E.T.; Lee, S.W.; Koo, K.I.; Suaning, G.J.; Lovell, N.H.; Cho, D.-I.; et al. In vitro biocompatibility of various polymer-based microelectrode arrays for retinal prosthesis. Investig. Ophthalmol. Vis. Sci. 2012, 53, 2653-2657. [CrossRef] [PubMed]

131. Varan, C.; Bilensoy, E. Cationic PEGylated polycaprolactone nanoparticles carrying post-operation docetaxel for glioma treatment. Beilstein J. Nanotechnol. 2017, 8, 1446-1456. [CrossRef]

132. Tian, J.; Min, Y.; Rodgers, Z.; Wan, X.; Qiu, H.; Mi, Y.; Tian, X.; Wagner, K.T.; Caster, J.M.; Qi, Y.; et al. Nanoparticle delivery of chemotherapy combination regimen improves the therapeutic efficacy in mouse models of lung cancer. Nanomedicine 2017, 13, 1301-1307. [CrossRef]

133. Vauthier, C.; Bouchemal, K. Methods for the preparation and manufacture of polymeric nanoparticles. Pharm. Res. 2009, 26, 1025-1058. [CrossRef]

134. Bilati, U.; Allémann, E.; Doelker, E. Development of a nanoprecipitation method intended for the entrapment of hydrophilic drugs into nanoparticles. Eur. J. Pharm. Sci. 2005, 24, 67-75. [CrossRef]

135. Soppimath, K.S.; Aminabhavi, T.M.; Kulkarni, A.R.; Rudzinski, W.E. Biodegradable polymeric nanoparticles as drug delivery devices. J. Control. Release 2001, 70, 1-20. [CrossRef]

136. Alhakamy, N.A.; Md, S. Repurposing itraconazole loaded PLGA nanoparticles for improved antitumor efficacy in non-small cell lung cancers. Pharmaceutics 2019, 11, 685. [CrossRef]

137. Pretel, E.; Arias, J.L.; Cabeza, L.; Melguizo, C.; Prados, J.; Mallandrich, M.; Suñer, J.; Clares, B. Development of biomedical 5-fluorouracil nanoplatforms for colon cancer chemotherapy: Influence of process and formulation parameters. Int. J. Pharm. 2017, 530, 155-164. [CrossRef]

138. Baeza, A.; Guisasola, E.; Ruiz-Hernández, E.; Vallet-Regí, M. Magnetically triggered multidrug release by hybrid mesoporous silica nanoparticles. Chem. Mater. 2012, 24, 517-524. [CrossRef]

139. Schmaljohann, D. Thermo- and pH-responsive polymers in drug delivery. Adv. Drug Deliv. Rev. 2006, 58, 1655-1670. [CrossRef] [PubMed]

140. Kalhapure, R.S.; Renukuntla, J. Thermo- and pH dual responsive polymeric micelles and nanoparticles. Chem. Biol. Interact. 2018, 295, 20-37. [CrossRef]

141. Mai, B.T.; Fernandes, S.; Balakrishnan, P.B.; Pellegrino, T. Nanosystems based on magnetic nanoparticles and thermo- or pH-responsive polymers: An update and future perspectives. Acc. Chem. Res. 2018, 51, 999-1013. [CrossRef]

142. Huang, Y.; Tang, Z.; Zhang, X.; Yu, H.; Sun, H.; Pang, X.; Chen, X. pH-Triggered charge-reversal polypeptide nanoparticles for cisplatin delivery: Preparation and in vitro evaluation. Biomacromolecules 2013, 14, 2023-2032. [CrossRef] [PubMed]

143. Ghafari, M.; Haghiralsadat, F.; Falahati-Pour, S.K.; Reza, J.Z. Development of a novel liposomal nanoparticle formulation of cisplatin to breast cancer therapy. J. Cell. Biochem. 2020, 121, 3584-3592. [CrossRef] 